\title{
MAPPING KNOWLEDGE MANAGEMENT RESEARCH: A BIBLIOMETRIC OVERVIEW
}

\author{
Shashi ${ }^{1}$, Piera CENTOBELLI ${ }^{2}$, \\ Roberto CERCHIONE ${ }^{3}$, Jose M. MERIGO ${ }^{4,5}$ \\ ${ }^{1}$ Chitkara Business School, Chitkara University, Punjab, India \\ ${ }^{2}$ Department of Industrial Engineering, University of Naples Federico II, Naples, Italy \\ ${ }^{3}$ Department of Engineering, University of Naples Parthenope, Naples, Italy \\ ${ }^{4}$ Department of Management Control and Information Systems, \\ School of Economics and Business, University of Chile, Santiago, Chile \\ ${ }^{5}$ School of Systems, Management and Leadership, Faculty of Engineering and Information Technology, \\ University of Technology Sydney, Ultimo, 2007 NSW, Australia
}

Received 31 July 2019; accepted 15 November 2020; first published online 28 December 2021

\begin{abstract}
In recent years, knowledge management (KM) has consistently attained considerably growing research attention. Consequently, several literature reviews have been performed addressing different topic areas of KM. This paper seeks to present a comprehensive bibliometric and network analysis on KM to understand its development from the perspective of academic communities. Subsequently, it seeks to identify the structure of associations between prior and current themes, predict emerging trends and offer a longitudinal perspective on KM research. This study used web of science database and the initial sample was trimmed down by considering only the articles contributing to KM literature, and further 8,721 KM papers published in the last 30 years were systematically evaluated. The descriptive statistics and science mapping methods employing co-citation analysis were performed with VOSviewer software. In the descriptive analysis, we have analysed publication trends over time, geographical localization of the contributing institutions, journals, most prolific authors, top-performing institutions and most cited articles. Science mapping analysis is based on co-word analysis and co-citations analysis, namely articles' co-citations and authors' co-citations. The main findings of this paper will help researchers and academicians to develop knowledge in a specific sub-field by analysing the research outcomes of the papers included in the body of literature.
\end{abstract}

Keywords: knowledge management, Web of Science, bibliometric analysis, network analysis, VOSviewer.

JEL Classification: D83, O32, O33, Q55.

${ }^{*}$ Corresponding author. E-mail: roberto.cerchione@uniparthenope.it

Copyright $\odot 2021$ The Author(s). Published by Vilnius Gediminas Technical University

This is an Open Access article distributed under the terms of the Creative Commons Attribution License (http://creativecommons. org/licenses/by/4.0/), which permits unrestricted use, distribution, and reproduction in any medium, provided the original author and source are credited. 


\section{Introduction}

Over the past 20 years, research on knowledge management (KM) has witnessed considerable attention throughout the world and is well at the end of its third decade of investigation. The KM is becoming a strategic factor for all industries to survive in today's dynamic global business competition (Cerchione et al., 2020; Kaklauskas \& Kanapeckiene, 2005).

The concept of knowledge has been analysed in literature from different perspectives concerning what is knowledge (Lin \& Ha, 2015), where it is embedded (Buenstorf \& Costa, 2018; Lönnqvist, 2017; Miklosik et al., 2019), and how it can be classified (Polanyi, 1958; Nonaka, 1994; Holsapple, 2005). Starting from these conceptualizations, the interesting recent trends have been appeared such as impact of knowledge risk management on performance (Durst et al., 2019), market knowledge sourcing determinants (Endres et al., 2020), heterogeneous knowledge ties (Maghssudipour et al., 2020), role of international joint venture in managing and exploiting knowledge (Zhang et al., 2018), KM and green innovation (Abbas \& Sağsan, 2019). These trends have given unique conceptualization in the KM domain dealing with efficient and effective KM processes, as well as systematic strategies pertaining to knowledge creation, processing, sharing, and execution (Raudeliūnienė et al., 2018).

Besides, in the past, a number of reviews on the topic of KM have been published in recent years. Few of them have investigated the KM in specific subject areas (Cerchione et al., 2020), while others have shed light on several aspects: major trends and challenges in KM (Asrar \& Anwar, 2016), key KM approaches (Alexandru et al., 2019), processes for exploration and exploitation of knowledge (Centobelli et al., 2019), KM in strategic alliance (Tsai, 2016), KM and firm performance (Inkinen, 2016; Sulistio \& Dianawati, 2020), corporate culture and KM (Buckova, 2017), KM and sustainability (López-Torres et al., 2019), KM in SMEs and startups (Castagna et al., 2020) and KM performance measurement (Asiaei \& Bontis, 2019; Cardoni et al., 2020). These reviews have identified few research areas and research questions in the literature to be analysed for further research.

Despite the growing interest in KM and the number of review papers already published, there is a scarcity of contributions analysing how the whole KM academic research has evolved over the time. Thus, the aim of this paper is to answer the following research questions: 1) what are the key topics covered widely in literature? 2) which papers contributed more to the KM field? 3) what is co-words structure in the literature? 4) what is the social structure based on the authors' co-authorship? and 5) what is the co-citation based structure of articles and authors?

The remain of the paper is organised as follows: Section 1 presents the research methodology used in this paper. Section 2 and Section 3 discuss the results of the performance analysis and science mapping, respectively. Finally, we draw our conclusions and future research directions in Section 5.

\section{Research methodology}

In this paper, we employed the WoS database a digital platform globally acknowledged among scholars for its quality standards (Mulet-Forteza et al., 2019) that makes it one of the most used tools for searching and analysing both publications and journals among other 
databases like Scopus. Many researchers dealing with bibliometric analysis papers adopt WoS since it allows downloading properly all the relevant bibliometric information needed for this approach and performs much better than other databases in the accuracy (Wang \& Waltman, 2016). Furthermore, researchers emphasized that deploying multiple different databases arise the issue of data homogenization which negatively impacts results (Mariani \& Borghi, 2019). We further intend to perform co-citation analysis considering the cited references inside the same papers collected from WoS. This approach enables to recognize the additional pertinent literature, even from other databases, that may be overlooked during standard approaches of literature search (Trujillo \& Long, 2018).

The following keywords were used during December 2019 to retrieve the papers: ("knowledge manag" OR "knowledge creat*" OR "knowledge stor*" OR "knowledge shar ${ }^{\star}$ " OR "knowledge transf $f^{\star}$ " OR "knowledge appl $1^{\star ”}$ OR "knowledge diffus $s^{\star ”}$ OR "knowledge acqui $i^{\star ”}$ OR "knowledge integrat $t^{\star}$ " OR "knowledge utili*” OR "knowledge us" OR "knowledge combinat" OR "knowledge assimilat ${ }^{\star *}$ OR "knowledge adopt*" OR "knowledge exploit*" OR "knowledge explor" ${ }^{\star}$ ). The use of these keywords makes it possible to select papers dealing with the main knowledge management processes analysed in the body of literature (i.e., knowledge acquisition, knowledge creation, knowledge storage, knowledge sharing, knowledge transfer, knowledge diffusion, knowledge application, knowledge integration, knowledge utilization, knowledge use, knowledge combination, knowledge assimilation, knowledge adoption, knowledge exploitation, and knowledge exploration). We only considered papers published in English language and restricted the literature search between the time period of 1990 and 2019. Further, we excluded the conference proceedings, editorial notes, book chapters, book reviews, and extended abstracts. Subsequently, we trimmed down the initial sample by eliminating the irrelevant articles which do not significantly contribute to KM literature. A validation criterion regards the integration of contributions that were not found through the research string and/or comprised in the selected academic database but were cited in the literature on KM. Therefore, this criterion validates the choice of the search string and academic database. Finally, 8,721 papers were retrieved which include reviews and full papers written in English language and published until 2019. Finally, sample papers were analysed using two bibliometric procedures: performance analysis and science mapping.

\section{Performance analysis results}

Figure 1 shows that research on KM increases over the years. Despite the growth between 1990 and 1999 was very slow, the scientific literature on KM in peer-reviewed journals increased significantly after 1999. It passed from 619 articles published until 1999 to 4,422 articles published between 2000 and 2014. More recently the growth was even more significant with 3,680 papers published only in the last five years. This aspect confirms that the research on $\mathrm{KM}$ has attained growing research attention in recent times.

The statistics confirm that 2,353 journals have contributed total of 8,721 articles published on KM. For the journal ranking, in case of equal publications by two or more journals, the number of citations is considered for ranking. Table 1 show that the 25 most contributing journals have published a total of 1,930 articles representing about $22.13 \%$ of all identified 


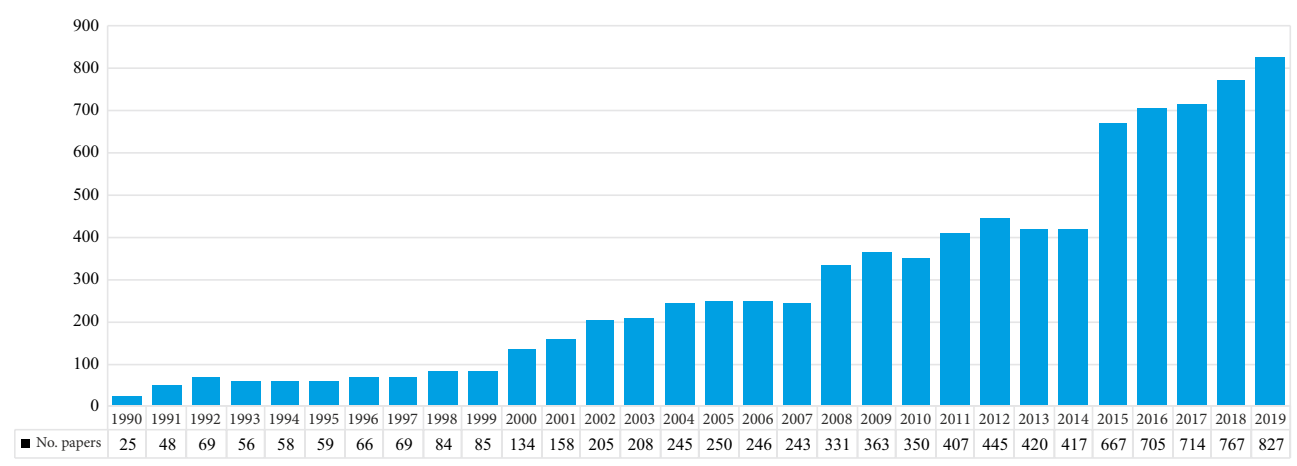

Figure 1. Publication trend over the time

articles. Therefore, the contribution of the remaining 2,328 journals is about $77.87 \%$. Notably, "Journal of Knowledge Management" emerges as the journal with the highest number of published articles on KM (409), followed by "Knowledge Management Research \& Practice" and "Expert Systems with Applications" with 190 and 154 articles published, respectively.

The analysis of journals with highest number of citations reveals that the top 25 journals are cited 107,696 times. "Journal of Knowledge Management" is also the journal with the highest number of citations received $(9,667)$. "Strategic Management Journal" and "MIS Quarterly" journals are not in the list of top 25 contributing journals, but they appear in the second and third place in the top 25 journals rank considering the number of citations received with 9,418 and 7,581 citations received, respectively (Table 1). These two journals represent the $24.76 \%$ of the total citations of the 25 most contributing journals. Similarly, "Knowledge Management Research \& Practice" is the second top contributing journal but not appeared in the top 25 list of most cited journals. If we compare the average citations per paper of "Strategic Management Journal" and "MIS Quarterly" with "Journal of Knowledge Management" and "Expert System with Applications" which are two leading journals (also appeared in the top-cited journal list) based on the number of papers published over the time, a large difference will be found.

Table 2 reports journals' metrics for the top 25 contributing journals. These journals cover eight subject areas. According to Buckley and Carter (1999), KM is a crossroad research topic focusing on different subjects even if, in line with the nature of the KM topic, "Business, Management and Accounting" and "Computer Science" emerged as the subject areas most frequently encountered. Therefore, indeed, Table 2 reports publications belonging to different subject areas, a wide range of journals, published in different countries under different publishers. For that reason, Neves and Da Silva (2016) suggest categorizing papers by the journal to support both researchers and practitioners in identifying who publish such topics in a particular domain. Among 25 journals, nine journals belong to "Elsevier", four to "Emerald", two to "Springer", two to "Taylor \& Francis". Remaining seven journals belong to "Inderscience", "World Scientific", "Association of Professional Managers in South Africa", "Sage”, “MDPI” "Wiley”, “Technische”, “Technischen”, and “Idea Group”, respectively. Meanwhile, eleven journals belong to the "United Kingdom", six to "Netherlands", four to "United States", one to "Germany", one to "South Africa", one to "Switzerland", and one to "Austria". 
Table 1. Distribution of the top 25 contributing and most cited journals

\begin{tabular}{|c|c|c|c|c|c|c|}
\hline \multicolumn{3}{|c|}{ Rank based on papers published } & \multicolumn{4}{|c|}{ Rank based on citations received } \\
\hline$\#$ & Journal & $\begin{array}{l}\text { No. of } \\
\text { articles }\end{array}$ & $\#$ & Journal & Citations & $\begin{array}{c}\text { Average } \\
\text { citations } \\
\text { per } \\
\text { article }\end{array}$ \\
\hline 1 & Journal of Knowledge Management & 409 & 1 & $\begin{array}{l}\text { Journal of Knowledge } \\
\text { Management }\end{array}$ & 9,667 & 23.63 \\
\hline 2 & $\begin{array}{l}\text { Knowledge Management Research \& } \\
\text { Practice }\end{array}$ & 190 & 2 & Strategic Management Journal & 9,418 & 367.72 \\
\hline 3 & Expert Systems with Applications & 154 & 3 & MIS Quarterly & 7,581 & 361.00 \\
\hline 4 & $\begin{array}{l}\text { International Journal of Information } \\
\text { Management }\end{array}$ & 103 & 4 & Organization Science & 7,130 & 310.00 \\
\hline 5 & $\begin{array}{l}\text { International Journal of Technology } \\
\text { Management }\end{array}$ & 96 & 5 & $\begin{array}{l}\text { Expert Systems with } \\
\text { Applications }\end{array}$ & 6,267 & 40.69 \\
\hline 6 & $\begin{array}{l}\text { Journal of Information \& Knowledge } \\
\text { Management }\end{array}$ & 72 & 6 & $\begin{array}{l}\text { Academy of Management } \\
\text { Journal }\end{array}$ & 5,879 & 367.43 \\
\hline 7 & $\begin{array}{l}\text { Vine Journal of Information and } \\
\text { Knowledge Management Systems }\end{array}$ & 63 & 7 & Management Science & 5,732 & 286.60 \\
\hline 8 & Journal of Business Research & 60 & 8 & $\begin{array}{l}\text { Journal of International } \\
\text { Business Studies }\end{array}$ & 4,653 & 172.33 \\
\hline 9 & Computers in Human Behavior & 59 & 9 & $\begin{array}{l}\text { Journal of Management } \\
\text { Information Systems }\end{array}$ & 4,480 & 224.00 \\
\hline 10 & Decision Support Systems & 55 & 10 & Information \& Management & 4,170 & 85.10 \\
\hline 11 & $\begin{array}{l}\text { South African Journal of Business } \\
\text { Management }\end{array}$ & 53 & 11 & Decision Support Systems & 3,978 & 72.32 \\
\hline 12 & $\begin{array}{l}\text { Industrial Management \& Data } \\
\text { Systems }\end{array}$ & 51 & 12 & $\begin{array}{l}\text { International Journal of } \\
\text { Information Management }\end{array}$ & 3,972 & 38.56 \\
\hline 13 & $\begin{array}{l}\text { Journal of Computer Information } \\
\text { Systems }\end{array}$ & 50 & 13 & $\begin{array}{l}\text { California Management } \\
\text { Review }\end{array}$ & 3,952 & 359.27 \\
\hline 14 & Information \& Management & 49 & 14 & $\begin{array}{l}\text { International Journal of } \\
\text { Human-Computer Studies }\end{array}$ & 3,620 & 92.82 \\
\hline 15 & Research Policy & 49 & 15 & $\begin{array}{l}\text { Journal of Management } \\
\text { Studies }\end{array}$ & 3,532 & 130.81 \\
\hline 16 & Journal of Information Science & 48 & 16 & Research Policy & 3,487 & 71.16 \\
\hline 17 & Sustainability & 47 & 17 & $\begin{array}{l}\text { Organizational Behavior And } \\
\text { Human Decision Processes }\end{array}$ & 2,638 & 293.11 \\
\hline 18 & $\begin{array}{l}\text { Journal of Universal Computer } \\
\text { Science }\end{array}$ & 44 & 18 & Long Range Planning & 2,516 & 132.42 \\
\hline 19 & Knowledge and Process Management & 42 & 19 & Journal of Business Research & 2,452 & 40.9 \\
\hline 20 & $\begin{array}{l}\text { International Journal of Human } \\
\text { Resource Management }\end{array}$ & 40 & 20 & Journal of Business Research & 2,362 & 46.31 \\
\hline 21 & $\begin{array}{l}\text { International Journal of Knowledge } \\
\text { Management }\end{array}$ & 40 & 21 & $\begin{array}{l}\text { Academy of Management } \\
\text { Review }\end{array}$ & 2,362 & 337.42 \\
\hline 22 & Knowledge-Based Systems & 40 & 22 & $\begin{array}{l}\text { Journal of Information } \\
\text { Science }\end{array}$ & 2,120 & 44.16 \\
\hline 23 & $\begin{array}{l}\text { International Journal of Human- } \\
\text { Computer Studies }\end{array}$ & 39 & 23 & $\begin{array}{l}\text { Progress in Human } \\
\text { Geography }\end{array}$ & 1,996 & 665.33 \\
\hline 24 & Scientometrics & 39 & 24 & $\begin{array}{l}\text { International Journal } \\
\text { of Human Resource } \\
\text { Management }\end{array}$ & 1,872 & 46.8 \\
\hline 25 & Management Decision & 38 & 25 & Organization Studies & 1,860 & 109.41 \\
\hline
\end{tabular}




\begin{tabular}{|c|c|c|c|c|c|c|c|c|c|c|c|}
\hline 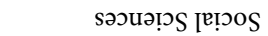 & & - & & - & - & - & - & & & & \\
\hline 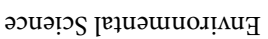 & & & & & & & & & & & \\
\hline 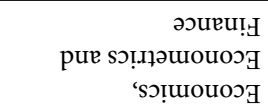 & & & & & & & & & & & \\
\hline әวиว!̣ .əłnduоว & & & - & - & - & - & - & - & & - & \\
\hline 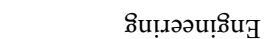 & & & - & & & & & & & & \\
\hline 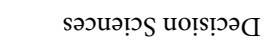 & & & & & & & & & & - & \\
\hline 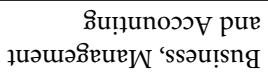 & $\bullet$ & $\bullet$ & & & - & & - & • & & • & $\bullet$ \\
\hline 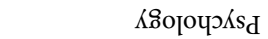 & & & & & & & & & - & - & \\
\hline 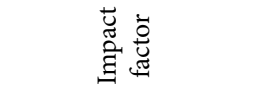 & $\stackrel{8}{\stackrel{8}{+}}$ & $\stackrel{\infty}{\stackrel{\infty}{\rightarrow}}$ & ते & : & $\stackrel{\circ}{=}$ & 1 & 1 & 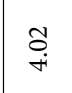 & $\stackrel{m}{m}$ & $\begin{array}{l}\sharp \\
\infty \\
\dot{m}\end{array}$ & ?ִ \\
\hline 乐苛 & 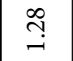 & $\underset{\mathfrak{0}}{\mathfrak{N}}$ & $\stackrel{9}{ت}$ & $\sqrt{-}$ & in & $\frac{9}{0}$ & 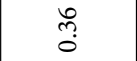 & $\stackrel{\infty}{\infty}$ & 고 & $\stackrel{n}{\stackrel{n}{i}}$ & 今. \\
\hline 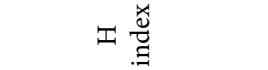 & 으 & $\stackrel{\text { m }}{2}$ & ర్ర & $\bar{a}$ & in & 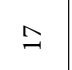 & $\stackrel{\leftrightarrow}{\sim}$ & $\stackrel{\infty}{n}$ & $\hat{m}$ & $\widehat{\Xi}$ & $\simeq$ \\
\hline 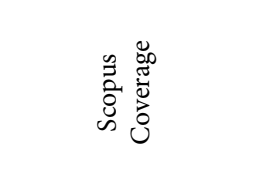 & 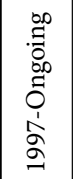 & 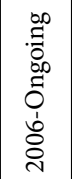 & 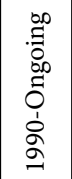 & 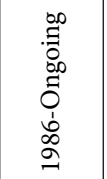 & 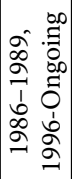 & 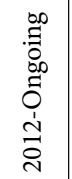 & $\begin{array}{l}.0 \\
.0 \\
0 \\
0 \\
0 \\
1 \\
0 \\
0 \\
0\end{array}$ & 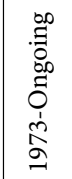 & 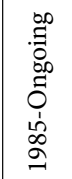 & $\begin{array}{l}\infty \\
\stackrel{0}{0} \\
\infty \\
0 \\
0 \\
1 \\
0 \\
0 \\
=\end{array}$ & 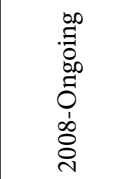 \\
\hline 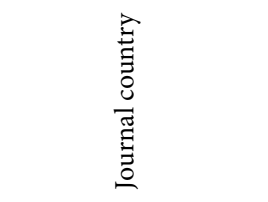 & 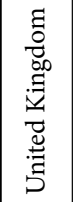 & 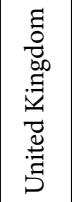 & 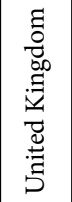 & 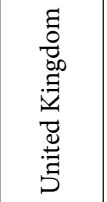 & 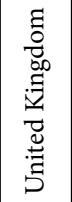 & 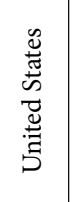 & 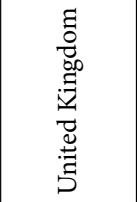 & 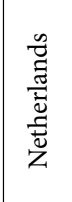 & 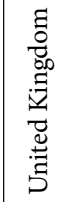 & 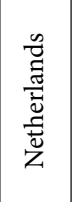 & 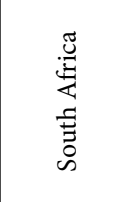 \\
\hline 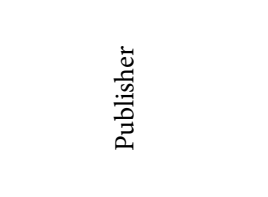 & 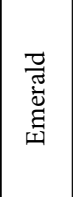 & 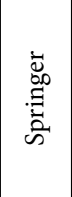 & 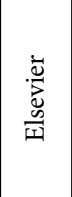 & 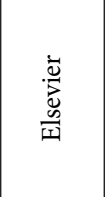 & 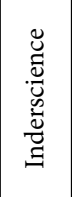 & 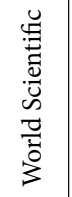 & 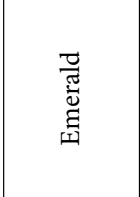 & 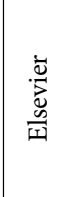 & 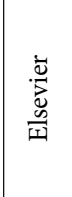 & 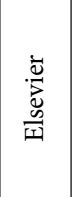 & 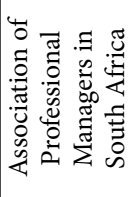 \\
\hline 胥 & 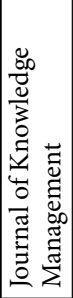 & 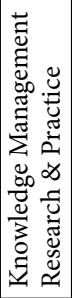 & 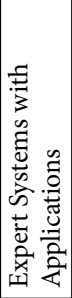 & 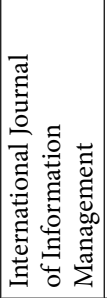 & 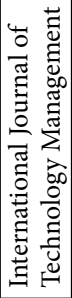 & 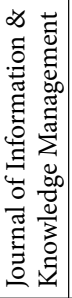 & 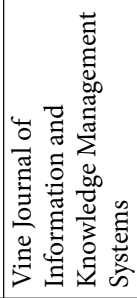 & 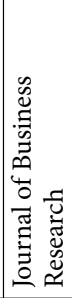 & 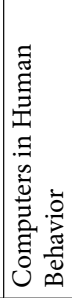 & 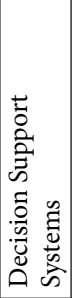 & 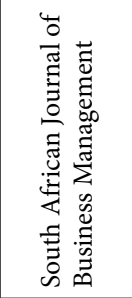 \\
\hline
\end{tabular}




\begin{tabular}{|c|c|c|c|c|c|c|c|c|c|c|c|c|c|c|}
\hline 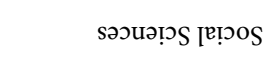 & & - & & & - & - & & & & & & • & • & \\
\hline 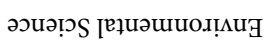 & & & & & & - & & & & & & & & \\
\hline 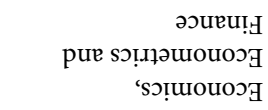 & & & & & & & & & & & & & & \\
\hline 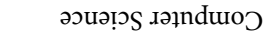 & - & - & - & & - & & - & & & - & - & - & - & \\
\hline ภิu!̣วəu!̣ôt & - & & & - & & & & & & & & - & & \\
\hline 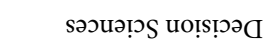 & & & - & - & & & & & & & - & & & - \\
\hline 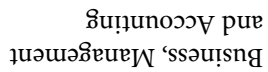 & - & & - & $\bullet$ & & & & $\bullet$ & • & $\bullet$ & • & & & - \\
\hline 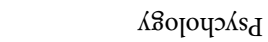 & & & & & & & & & & & & & & \\
\hline 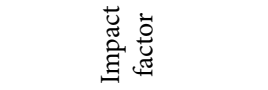 & $\stackrel{N}{N}$ & $\stackrel{\circ}{=}$ & $\stackrel{7}{\sim}$ & 7ั & $\widetilde{\sim}$ & นึે & $\bar{a}$ & 1 & $\stackrel{n}{m}$ & 1 & $\stackrel{9}{10}$ & $\underset{i}{8}$ & $\stackrel{N}{a}$ & $\stackrel{2}{2}$ \\
\hline 点苛 & $\stackrel{m}{\rightarrow}$ & $\stackrel{\infty}{\infty}$ & $\stackrel{-}{N}$ & $\begin{array}{l}F \\
m\end{array}$ & $\hat{\beta}$ & in & $\stackrel{m}{0}$ & ஸे & $\stackrel{n}{2}$ & ़ֻڤ & $\stackrel{0}{\stackrel{0}{+}}$ & $\stackrel{\infty}{\infty}$ & $\exists$ & 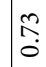 \\
\hline 工泀 & $\infty$ & in & 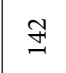 & ֻั & in & in & $\stackrel{\infty}{+}$ & $\stackrel{\infty}{m}$ & $\stackrel{\infty}{\sigma}$ & 2 & హ゙ & 。ㅇ & $2 \alpha$ & $\infty$ \\
\hline 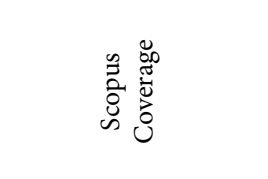 & $\begin{array}{l}\infty \\
\stackrel{\Xi}{0} \\
\infty \\
0 \\
0 \\
1 \\
0 \\
0 \\
0\end{array}$ & 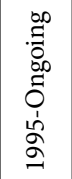 & 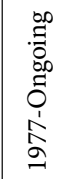 & 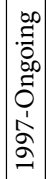 & 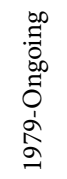 & 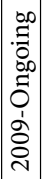 & 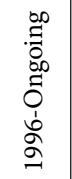 & 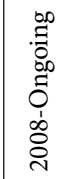 & 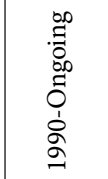 & 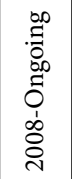 & 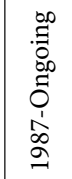 & 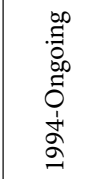 & 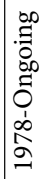 & 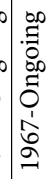 \\
\hline 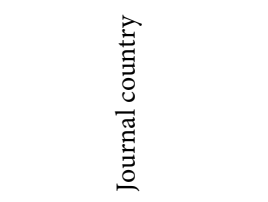 & 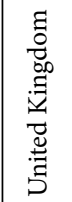 & 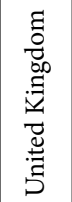 & 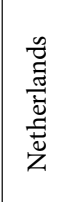 & 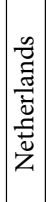 & 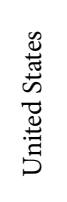 & 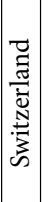 & 萢 & 苛 & 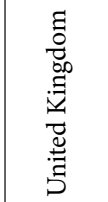 & 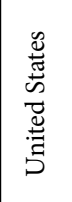 & 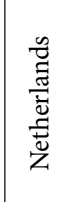 & 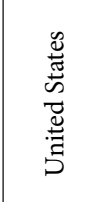 & 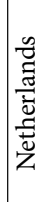 & 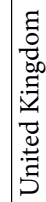 \\
\hline 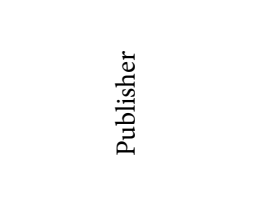 & 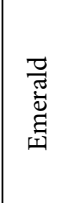 & 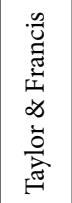 & 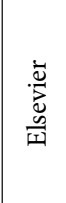 & 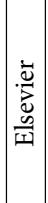 & 总 & $\overrightarrow{\mathrm{z}}$ & 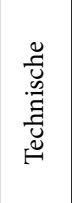 & $\frac{\overrightarrow{0}}{3}$ & 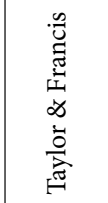 & 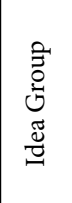 & 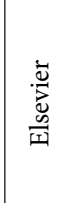 & 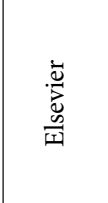 & 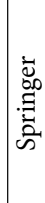 & 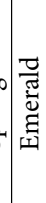 \\
\hline $\begin{array}{l}\text { 点 } \\
\stackrel{\Xi}{\Xi}\end{array}$ & 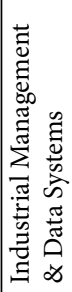 & 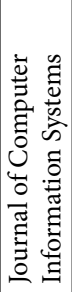 & 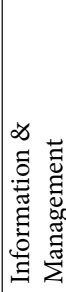 & 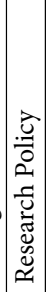 & 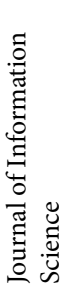 & 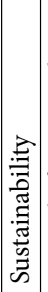 & 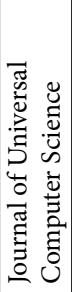 & 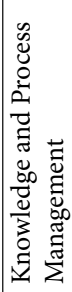 & 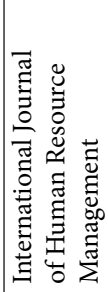 & 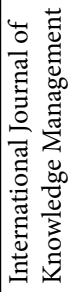 & 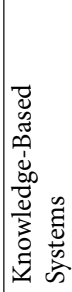 & 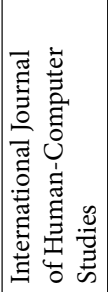 & 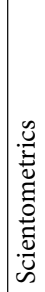 & 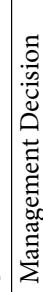 \\
\hline
\end{tabular}


Herein, "Research Policy", and "Expert Systems with Applications" have the highest H-index values (206, and 162, respectively). Besides, the "Research Policy" and "Information \& Management" emerged as leading SJR scorers with 3.41 and 1.72, respectively. "Research Policy" and "Knowledge-Based Systems" appeared as high impact factor journals with 5.42 and 5.10 impact factor values, respectively (Table 2).

\subsection{Author influence}

The results show that there are 19,175 authors publishing 8,721 papers on KM. Table 3 reports the 20 most prolific authors (in terms of number of articles published), the number of citations received, the number of papers they published, their $\mathrm{H}$-index and affiliation. Results show that Akhavan Peyman from Malek Ashtar University of Technology, Tehran (Iran) is the most prolific author and published 16 articles followed by Kianto Aino from Lappeenrannan Teknillinen Yliopisto, Lappeenranta (Finland) with 14 articles. In the third place among the top contributing authors, Georg Von Krogh from the ETH Zürich University (Switzerland) is also the dominant cited author with 1,486 citations and the highest average citations per article (123.83).

\subsection{Affiliation and country statistics}

Figure 2 indicates the origin of the institutions who contributed most in the advancement of the KM research. Notably, in case of equal number of articles by two or more countries, the number of citations is considered for ranking. It can be concluded that United States, United Kingdom and China based institutions are the major contributors. Most importantly, Asian institutions' contribution is quite less, only few Northeast Asian countries (China, Taiwan, and South Korea) have significantly contributed to the KM research. In detail, considering the top 5 contributing countries, United States of America published in total 1,832 articles, United Kingdom 992, China 866, Taiwan 619, and Canada 447 articles. Besides, African countries have not published (e.g., Chad, Congo, and Eritrea) or published less than 10 papers (e.g., Botswana, Cameroon, Gabon, Namibia, Somalia, Sudan, and Zimbabwe). The limited use of information and communication technology, as well as the digital divide between the different countries, may be a reason behind such difference of contribution between African, American, and European countries.

Table 4 reports the organization's ranking based on the number of citations received by articles divided by the number of articles published. The University of Illinois published 39 articles and these articles have been cited 3,155 times, and thus obtained the highest value of citations per article (80.89), followed by the National University of Singapore who published 46 articles cited 2,817 times (61.23 average citations per article). This implies that these universities are the most impact-full universities in the KM filed. Among the 25 top institutions (in terms of average citations per paper), six are from Taiwan, three from Canada and UK, two from Singapore, Hong Kong, Malaysia, China and Iran and one from South Korea and United States. This distribution is almost in line with the distribution of the most prolific authors (Table 3). 
Table 3. The 20 most prolific authors and related affiliations

\begin{tabular}{|c|c|c|c|c|c|}
\hline Author & Citations & $\begin{array}{l}\text { No. of } \\
\text { papers }\end{array}$ & $\begin{array}{c}\text { Average } \\
\text { citations } \\
\text { per article }\end{array}$ & $\begin{array}{l}\text { Scopus } \\
\text { h-index }\end{array}$ & $\begin{array}{c}\text { Current affiliation as per Scopus } \\
\text { database }\end{array}$ \\
\hline Akhavan, Peyman & 146 & 16 & 9.12 & 20 & $\begin{array}{l}\text { Malek Ashtar University of } \\
\text { Technology, Tehran, Iran }\end{array}$ \\
\hline Kianto, Aino & 345 & 14 & 24.64 & 19 & $\begin{array}{l}\text { Lappeenrannan Teknillinen } \\
\text { Yliopisto, Lappeenranta, Finland }\end{array}$ \\
\hline Von Krogh, Georg & 1,486 & 12 & 123.83 & 38 & $\begin{array}{l}\text { ETH Zürich, Zurich ZH, } \\
\text { Switzerland }\end{array}$ \\
\hline Lin, Hsiu-Fen & 1,119 & 12 & 93.25 & 31 & $\begin{array}{l}\text { National Taiwan Ocean University, } \\
\text { Keelung, Taiwan }\end{array}$ \\
\hline Serenko, Alexander & 455 & 12 & 37.91 & 30 & $\begin{array}{l}\text { University of Toronto, Toronto, } \\
\text { Canada }\end{array}$ \\
\hline Lin, Chieh-Peng & 424 & 12 & 35.33 & 28 & $\begin{array}{l}\text { National Chiao Tung University } \\
\text { Taiwan, Hsinchu, Taiwan }\end{array}$ \\
\hline Bontis, Nick & 367 & 12 & 30.58 & 43 & $\begin{array}{l}\text { McMaster University, DeGroote } \\
\text { School of Business, Hamilton, } \\
\text { Canada }\end{array}$ \\
\hline Pedersen, Torben & 602 & 11 & 54.72 & 27 & $\begin{array}{l}\text { Aalborg Universitet, Aalborg, } \\
\text { Denmark }\end{array}$ \\
\hline Liao, Shu-Hsien & 485 & 11 & 44.09 & 28 & $\begin{array}{l}\text { Tamkang University, Tamsui, } \\
\text { Taiwan }\end{array}$ \\
\hline Lin, Binshan & 249 & 11 & 22.63 & 41 & $\begin{array}{l}\text { Louisiana State University in } \\
\text { Shreveport, Shreveport, United } \\
\text { States }\end{array}$ \\
\hline Li, Yuan & 229 & 11 & 20.81 & 34 & Tongji University, Shanghai, China \\
\hline Esposito, Emilio & 207 & 11 & 18.81 & 20 & $\begin{array}{l}\text { Università degli Studi di Napoli } \\
\text { Federico II, Naples, Italy }\end{array}$ \\
\hline Oliveira, Mírian & 59 & 11 & 5.36 & 7 & $\begin{array}{l}\text { Instituto Superior de Economia e } \\
\text { Gestão, Universidade de Lisboa, } \\
\text { Lisbon, Portugal }\end{array}$ \\
\hline Ooi, Keng-Boon & 294 & 10 & 29.40 & 41 & $\begin{array}{l}\text { UCSI University, Kuala Lumpur, } \\
\text { Malaysia }\end{array}$ \\
\hline Chua, Alton Y.K. & 237 & 10 & 23.70 & 28 & $\begin{array}{l}\text { Wee Kim Wee School of } \\
\text { Communication and Information, } \\
\text { Singapore }\end{array}$ \\
\hline Cerchione, Roberto & 203 & 10 & 20.30 & 15 & $\begin{array}{l}\text { Parthenope University of Naples, } \\
\text { Naples, Italy }\end{array}$ \\
\hline Mueller, Julia & 429 & 9 & 47.36 & 9 & $\begin{array}{l}\text { Martin-Universität Halle- } \\
\text { Wittenberg, Halle, Germany }\end{array}$ \\
\hline Davison, Robert M. & 330 & 9 & 36.66 & 33 & $\begin{array}{l}\text { City University of Hong Kong, } \\
\text { Kowloon, Hong Kong }\end{array}$ \\
\hline Tseng, Shu-Mei & 261 & 9 & 29.00 & 13 & I-Shou University, Dashu, Taiwan \\
\hline Tsai, Ming-Tien & 254 & 9 & 28.22 & 19 & $\begin{array}{l}\text { Institute of International Business } \\
\text { No. 1, Tainan, Taiwan }\end{array}$ \\
\hline
\end{tabular}




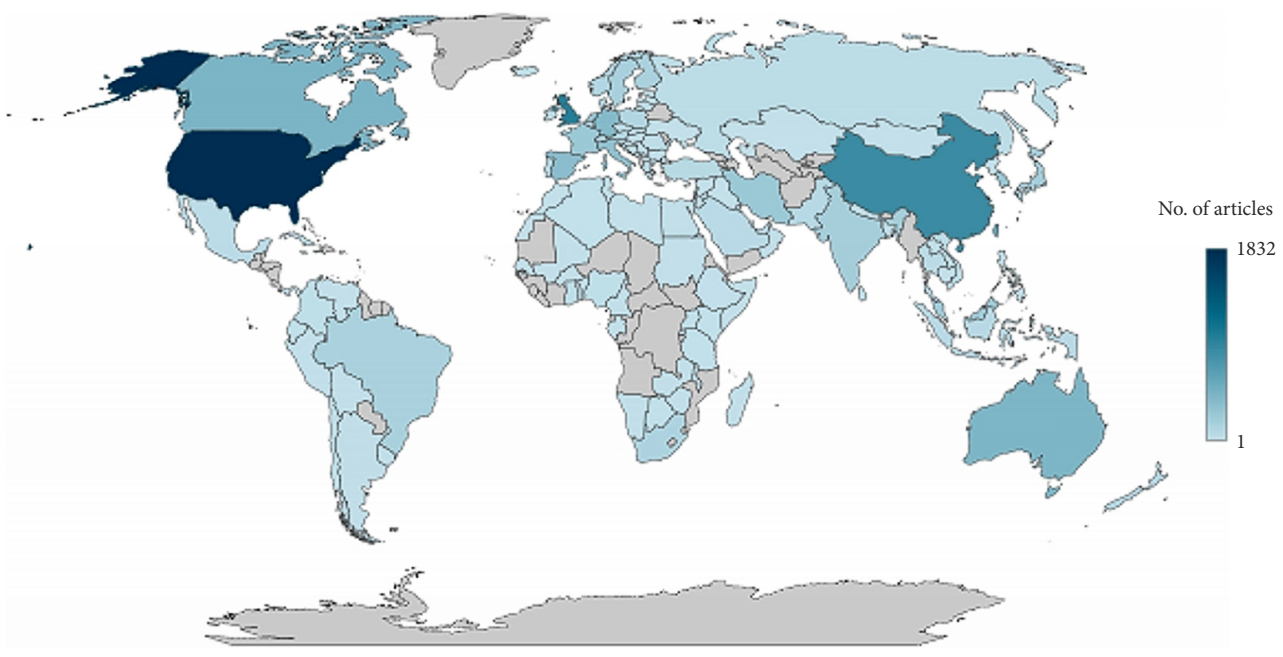

Figure 2. Geographical distribution of the KM papers

Table 4. Top 25 contributing institutions as per average citations per article

\begin{tabular}{|c|l|l|c|c|c|c|}
\hline Rank & \multicolumn{1}{|c|}{ Institutions } & Country & $\begin{array}{c}\text { Number } \\
\text { of Publi- } \\
\text { cations }\end{array}$ & Citations & $\begin{array}{c}\text { Average } \\
\text { citations per } \\
\text { article }\end{array}$ & QS 2019 \\
\hline 1 & University of Illinois & $\begin{array}{l}\text { United } \\
\text { States }\end{array}$ & 39 & 3,155 & 80.89 & 71 \\
\hline 2 & National University of Singapore & Singapore & 46 & 2,817 & 61.23 & 11 \\
\hline 3 & National Central University & Taiwan & 50 & 2,846 & 56.86 & 415 \\
\hline 4 & City University of Hong Kong & $\begin{array}{l}\text { Hong } \\
\text { Kong }\end{array}$ & 66 & 3,712 & 56.24 & 55 \\
\hline 5 & $\begin{array}{l}\text { Nanyang Technological } \\
\text { University }\end{array}$ & Singapore & 52 & 2,588 & 49.76 & 12 \\
\hline 6 & University of Toronto & Canada & 58 & 2,864 & 49.37 & 28 \\
\hline 7 & University of Warwick & $\begin{array}{l}\text { United } \\
\text { Kingdom }\end{array}$ & 35 & 1,590 & 45.42 & 54 \\
\hline 8 & University of Nottingham & $\begin{array}{l}\text { United } \\
\text { Kingdom }\end{array}$ & 36 & 1,507 & 41.86 & 82 \\
\hline 9 & National Sun Yat-sen University & Taiwan & 35 & 1,101 & 31.45 & 402 \\
\hline 10 & National Cheng Kung University & Taiwan & 80 & 2,418 & 30.22 & 234 \\
\hline 11 & National Taiwan University & Taiwan & 46 & 1,356 & 29.47 & 72 \\
\hline 12 & $\begin{array}{l}\text { Hong Kong Polytechnic } \\
\text { University }\end{array}$ & $\begin{array}{l}\text { Hong } \\
\text { Kong }\end{array}$ & 52 & 1,460 & 28.07 & 106 \\
\hline 13 & University of Sheffield & $\begin{array}{l}\text { United } \\
\text { Kingdom }\end{array}$ & 40 & 1,091 & 27.27 & 75 \\
\hline
\end{tabular}


End of Table 4

\begin{tabular}{|c|l|l|c|c|c|c|}
\hline Rank & \multicolumn{1}{|c|}{ Institutions } & Country & $\begin{array}{c}\text { Number } \\
\text { of Publi- } \\
\text { cations }\end{array}$ & Citations & $\begin{array}{c}\text { Average } \\
\text { citations per } \\
\text { article }\end{array}$ & QS 2019 \\
\hline 14 & McMaster University & Canada & 37 & 902 & 24.37 & 146 \\
\hline 15 & Monash University & Malaysia & 37 & 834 & 22.54 & 59 \\
\hline 16 & Seoul National University & $\begin{array}{l}\text { South } \\
\text { Korea }\end{array}$ & 37 & 686 & 18.54 & 36 \\
\hline 17 & University of Alberta & Canada & 37 & 682 & 18.43 & 109 \\
\hline 18 & $\begin{array}{l}\text { National Taiwan University of } \\
\text { Science and Technology }\end{array}$ & Taiwan & 40 & 727 & 18.17 & 257 \\
\hline 19 & Chinese Academy of Sciences & China & 40 & 671 & 16.75 & - \\
\hline 20 & National Chiao Tung University & Taiwan & 41 & 651 & 15.87 & 208 \\
\hline 21 & Multimedia University & Malaysia & 36 & 414 & 11.5 & $801-1000$ \\
\hline 22 & Shanghai Jiao Tong University & China & 38 & 417 & 10.97 & 59 \\
\hline 23 & University of Tehran & Iran & 37 & 403 & 10.89 & $701-750$ \\
\hline 24 & University of São Paulo & Brazil & 36 & 346 & 9.61 & - \\
\hline 25 & Islamic Azad University & Iran & 91 & 461 & 5.06 & - \\
\hline
\end{tabular}

\subsection{Citation analysis}

The citations received by a paper indicates its impact and serves as quality indicator. Therefore, the highly cited papers demonstrate the greater contribution towards literature than less cited papers (Jiang et al., 2014). Citation analysis plays a crucial role in three main areas: 1) in investigating the relativeness of papers, institutions, and countries; 2) in serving as a metric of journal ranking; and 3) in exploring the intellectual formation of the domain. Table 5 reports the 25 papers with highest number of citations in WoS. "A dynamic theory of organizational knowledge creation" published in 1994 by Ikujiro Nonaka appeared as the most cited paper. This has been cited 6,453 times since 1994 (until 2019), and also has highest citations per year (258.12). "Knowledge management and knowledge management system: conceptual foundation and research issues" published in 2001 by Alavi M. and Leidner D. E. is the second most cited paper with 3,500 citations since 1996, and also has the second highest per year citations (194.44). Hence, these papers have given significant contributions to theory development in KM field.

The total number of citations received by each country indicates the impact of each country in the research domain. In Table 6 we summarize the top twenty cited countries. The United States of America emerges as the most cited country with 94,679 citations, followed by United Kingdom with 24,876 citations. As discussed in section 3.2, these two countries are also the highest contributors in terms of number of papers published. 
Table 5. Most cited articles

\begin{tabular}{|c|c|c|c|c|c|c|c|}
\hline \# & TC & Title & Author(s) & $\begin{array}{l}\text { Country of } \\
\text { first author }\end{array}$ & Journal & Year & $\mathrm{TC} / \mathrm{Y}$ \\
\hline 1 & 6453 & $\begin{array}{l}\text { A dynamic theory of } \\
\text { organizational knowledge } \\
\text { creation }\end{array}$ & Nonaka, I. & Japan & $\begin{array}{l}\text { Organization } \\
\text { Science }\end{array}$ & 1994 & 258.12 \\
\hline 2 & 3500 & $\begin{array}{l}\text { Review: Knowledge management } \\
\text { and knowledge management } \\
\text { system: conceptual foundation } \\
\text { and research issues }\end{array}$ & $\begin{array}{l}\text { Alavi, M., } \\
\text { Leidner, D. E. }\end{array}$ & United States & MIS Quarterly & 2001 & 194.44 \\
\hline 3 & 2352 & $\begin{array}{l}\text { Prospering in dynamically- } \\
\text { competitive environments: } \\
\text { Organizational capability as } \\
\text { knowledge integration }\end{array}$ & Grant, R. M. & United States & $\begin{array}{l}\text { Organization } \\
\text { Science }\end{array}$ & 1996 & 102.26 \\
\hline 4 & 2288 & $\begin{array}{l}\text { Towards principles for the design } \\
\text { of ontologies used for knowledge } \\
\text { sharing }\end{array}$ & Gruber, T. R. & United States & $\begin{array}{l}\text { International } \\
\text { Journal of } \\
\text { Human-Based } \\
\text { Studies }\end{array}$ & 1995 & 95.33 \\
\hline 5 & 2050 & $\begin{array}{l}\text { The knowledge-creating } \\
\text { company }\end{array}$ & Nonaka, I. & United States & $\begin{array}{l}\text { Harvard } \\
\text { Business } \\
\text { Review }\end{array}$ & 1991 & 73.21 \\
\hline 6 & 1906 & $\begin{array}{l}\text { Clusters and knowledge: Local } \\
\text { buzz, global pipelines and the } \\
\text { process of knowledge creation }\end{array}$ & $\begin{array}{l}\text { Bathelt, H., } \\
\text { Malmberg, A., } \\
\text { Maskell, P. }\end{array}$ & Germany & $\begin{array}{l}\text { Progress } \\
\text { in Human } \\
\text { Geography }\end{array}$ & 2004 & 127.07 \\
\hline 7 & 1820 & $\begin{array}{l}\text { Knowledge transfer in } \\
\text { intraorganizational network: } \\
\text { Effect of network position and } \\
\text { absorptive capacity on business } \\
\text { unit and performance }\end{array}$ & Tsai, W. P. & United States & $\begin{array}{l}\text { Academy of } \\
\text { Management } \\
\text { Journal }\end{array}$ & 2001 & 101.11 \\
\hline 8 & 1678 & $\begin{array}{l}\text { The concept of "ba": Building } \\
\text { a foundation for knowledge } \\
\text { creation }\end{array}$ & $\begin{array}{l}\text { Nonaka, I., } \\
\text { Konno, N. }\end{array}$ & Japan & $\begin{array}{l}\text { California } \\
\text { Management } \\
\text { Review }\end{array}$ & 1998 & 79.90 \\
\hline 9 & 1584 & $\begin{array}{l}\text { Behavioural intention formation } \\
\text { in knowledge sharing: Examining } \\
\text { the roles of extrinsic motivators, } \\
\text { social-psychological forces, and } \\
\text { organizational climates }\end{array}$ & $\begin{array}{l}\text { Bock, G. W., } \\
\text { Zmudu, R. W., } \\
\text { Kimm Y., } \\
\text { Lee, J. N. }\end{array}$ & Singapore & MIS Quarterly & 2005 & 113.14 \\
\hline 10 & 1547 & $\begin{array}{l}\text { Creating and managing a high- } \\
\text { performance knowledge-sharing } \\
\text { network: The Toyota case }\end{array}$ & $\begin{array}{l}\text { Dyer, J. H., } \\
\text { Nobeoka, K. }\end{array}$ & United States & $\begin{array}{l}\text { Strategic } \\
\text { Management } \\
\text { Journal }\end{array}$ & 2000 & 81.42 \\
\hline 11 & 1532 & $\begin{array}{l}\text { Social capital, networks, and } \\
\text { knowledge transfer }\end{array}$ & $\begin{array}{l}\text { Inkpen, A. C., } \\
\text { Tsang, E. W. K. }\end{array}$ & Singapore & $\begin{array}{l}\text { Academy of } \\
\text { Management } \\
\text { Review }\end{array}$ & 2005 & 109.43 \\
\hline 12 & 1507 & $\begin{array}{l}\text { Network structure and } \\
\text { knowledge transfer: The effect of } \\
\text { cohesion and range }\end{array}$ & $\begin{array}{l}\text { Reagans, R., } \\
\text { McEvily, B. }\end{array}$ & United States & $\begin{array}{l}\text { Administrative } \\
\text { Science } \\
\text { Quarterly }\end{array}$ & 2003 & 94.19 \\
\hline 13 & 1497 & $\begin{array}{l}\text { Strategic alliances and interfirm } \\
\text { knowledge transfer }\end{array}$ & $\begin{array}{l}\text { Mowery, D. C., } \\
\text { Oxley, J. E., } \\
\text { Silverman, B. S. }\end{array}$ & $\begin{array}{l}\text { United } \\
\text { States/ } \\
\text { Canada }\end{array}$ & $\begin{array}{l}\text { Strategic } \\
\text { Management } \\
\text { Journal }\end{array}$ & 1996 & 65.09 \\
\hline
\end{tabular}


End of Table 5

\begin{tabular}{|c|c|c|c|c|c|c|c|}
\hline \# & $\mathrm{TC}$ & Title & Author(s) & $\begin{array}{l}\text { Country of } \\
\text { first author }\end{array}$ & Journal & Year & $\mathrm{TC} / \mathrm{Y}$ \\
\hline 14 & 1453 & $\begin{array}{l}\text { Knowledge management: An } \\
\text { organizational capabilities } \\
\text { perspective }\end{array}$ & $\begin{array}{l}\text { Gold, A. H., } \\
\text { Malhotra, A., } \\
\text { Segars, A. H. }\end{array}$ & United States & $\begin{array}{l}\text { Journal of } \\
\text { Management } \\
\text { Information } \\
\text { System }\end{array}$ & 2001 & 78.78 \\
\hline 15 & 1330 & $\begin{array}{l}\text { SECI, ba and leadership: A } \\
\text { unified model of dynamic } \\
\text { knowledge creation }\end{array}$ & $\begin{array}{l}\text { Nonaka, I., } \\
\text { Toyama, R., } \\
\text { Konno, N. }\end{array}$ & Japan & $\begin{array}{l}\text { Long Range } \\
\text { Planning }\end{array}$ & 2000 & 80.72 \\
\hline 16 & 1301 & $\begin{array}{l}\text { Knowledge transfer: A basis for } \\
\text { competitive advance in firms }\end{array}$ & $\begin{array}{l}\text { Argote, L., } \\
\text { Ingram, P. }\end{array}$ & United States & $\begin{array}{l}\text { Organizational } \\
\text { Behaviour } \\
\text { and Human } \\
\text { Decision } \\
\text { Processes }\end{array}$ & 2000 & 70.00 \\
\hline 17 & 1222 & $\begin{array}{l}\text { Social capital, knowledge } \\
\text { acquisition, and knowledge } \\
\text { exploitation in young } \\
\text { technology-based firms }\end{array}$ & $\begin{array}{l}\text { Yli-Renko, } \\
\text { H., Autio, E., } \\
\text { Sapienza, H. J. }\end{array}$ & United States & $\begin{array}{l}\text { Strategic } \\
\text { Management } \\
\text { Journal }\end{array}$ & 2001 & 68.47 \\
\hline 18 & 1175 & $\begin{array}{l}\text { The strength of weak ties you can } \\
\text { trust: The mediating role of trust } \\
\text { in effective knowledge transfer }\end{array}$ & $\begin{array}{l}\text { Levin, D. Z., } \\
\text { Cross, R. }\end{array}$ & United States & $\begin{array}{l}\text { Management } \\
\text { Science }\end{array}$ & 2004 & 67.89 \\
\hline 19 & 1172 & $\begin{array}{l}\text { Understanding knowledge } \\
\text { sharing in virtual communities: } \\
\text { An integration of social capital } \\
\text { and social cognitive theories }\end{array}$ & $\begin{array}{l}\text { Chiu, C. M., } \\
\text { Hsu, M. H., } \\
\text { Wang, } \\
\text { Eric. T. G. }\end{array}$ & Taiwan & $\begin{array}{l}\text { Decision } \\
\text { Support } \\
\text { System }\end{array}$ & 2006 & 78.33 \\
\hline 20 & 1131 & $\begin{array}{l}\text { Successful knowledge } \\
\text { management projects }\end{array}$ & $\begin{array}{l}\text { Davenport, } \\
\text { T. H., De Long, } \\
\text { D. W., Beers, } \\
\text { M. C. }\end{array}$ & Austria & $\begin{array}{l}\text { Sloan } \\
\text { Management } \\
\text { Review }\end{array}$ & 1998 & 90.15 \\
\hline 21 & 1056 & $\begin{array}{l}\text { In search of complementarity } \\
\text { in innovation strategy: Internal } \\
\mathrm{R} \& \mathrm{D} \text { and external knowledge }\end{array}$ & $\begin{array}{l}\text { Cassiman, B., } \\
\text { Veugelers, R. }\end{array}$ & $\begin{array}{l}\text { Spain/ } \\
\text { Belgium }\end{array}$ & $\begin{array}{l}\text { Management } \\
\text { Science }\end{array}$ & 2006 & 53.86 \\
\hline 22 & 1017 & $\begin{array}{l}\text { Modularity, flexibility, and } \\
\text { knowledge management in } \\
\text { product and organization design }\end{array}$ & $\begin{array}{l}\text { Sanchez, R., } \\
\text { Mahoney, J. T. }\end{array}$ & Australia & $\begin{array}{l}\text { Strategic } \\
\text { Management } \\
\text { Journal }\end{array}$ & 1996 & 81.23 \\
\hline 23 & 930 & $\begin{array}{l}\text { Ambiguity and the process of } \\
\text { knowledge transfer in strategic } \\
\text { alliances }\end{array}$ & Simonin, B. L. & United States & $\begin{array}{l}\text { Strategic } \\
\text { Management } \\
\text { Journal }\end{array}$ & 1999 & 44.22 \\
\hline 24 & 842 & $\begin{array}{l}\text { Knowledge management } \\
\text { enablers, processes, and } \\
\text { organizational performance: An } \\
\text { integrative view and empirical } \\
\text { examination }\end{array}$ & $\begin{array}{l}\text { Lee, H., } \\
\text { Choi, B. }\end{array}$ & South Korea & $\begin{array}{l}\text { Journal of } \\
\text { Management } \\
\text { Information } \\
\text { Systems }\end{array}$ & 2003 & 46.50 \\
\hline 25 & 801 & $\begin{array}{l}\text { Knowledge sharing: A review } \\
\text { and directions for future } \\
\text { research. }\end{array}$ & $\begin{array}{l}\text { Wang, S., } \\
\text { Noe, R. A. }\end{array}$ & United States & $\begin{array}{l}\text { Human } \\
\text { Resource } \\
\text { Management } \\
\text { Review }\end{array}$ & 2010 & 52.63 \\
\hline
\end{tabular}

Note: TC - total citations; TC/Y - total citations/year. 
Table 6. Top 20 most cited countries

\begin{tabular}{|c|l|c|c|l|c|c|}
\hline Rank & Country & $\begin{array}{c}\text { No. of } \\
\text { documents }\end{array}$ & Rank & Country & Citations & $\begin{array}{c}\text { Per document } \\
\text { citations }\end{array}$ \\
\hline 1 & United States & 1882 & 1 & United States & 94679 & 50.31 \\
\hline 2 & $\begin{array}{l}\text { United } \\
\text { Kingdom }\end{array}$ & 992 & 2 & $\begin{array}{l}\text { United } \\
\text { Kingdom }\end{array}$ & 24876 & 25.07 \\
\hline 3 & China & 866 & 3 & Taiwan & 19329 & 31.23 \\
\hline 4 & Taiwan & 619 & 4 & China & 14463 & 16.70 \\
\hline 5 & Canada & 454 & 5 & Canada & 12301 & 27.09 \\
\hline 6 & Australia & 428 & 6 & Germany & 9459 & 24.01 \\
\hline 7 & Germany & 394 & 7 & South Korea & 8374 & 31.72 \\
\hline 8 & Spain & 359 & 8 & Spain & 8114 & 22.60 \\
\hline 9 & Italy & 324 & 9 & France & 7893 & 30.95 \\
\hline 10 & Netherlands & 269 & 10 & Singapore & 7617 & 62.43 \\
\hline 11 & South Korea & 264 & 11 & Japan & 6989 & 36.98 \\
\hline 12 & France & 255 & 12 & Netherlands & 6918 & 25.72 \\
\hline 13 & Iran & 244 & 13 & Australia & 6407 & 14.97 \\
\hline 14 & Malaysia & 218 & 14 & Sweden & 5727 & 33.30 \\
\hline 15 & Japan & 189 & 15 & Denmark & 5571 & 51.58 \\
\hline 16 & India & 188 & 16 & Finland & 5333 & 33.12 \\
\hline 17 & Sweden & 172 & 17 & Italy & 5281 & 16.30 \\
\hline 18 & Finland & 161 & 18 & Switzerland & 4678 & 38.66 \\
\hline 19 & Brazil & 160 & 19 & Norway & 2649 & 24.08 \\
\hline 20 & South Africa & 126 & 20 & Malaysia & 2553 & 11.71 \\
\hline & & & & & \\
\hline
\end{tabular}

\section{Science mapping}

Science mapping is an approach based on the use of techniques aimed to build bibliometric maps that describe how specific disciplines and scientific domains are conceptually and intellectually related. Among the most commonly used techniques there are co-citation analysis and the keywords' co-occurrence. We used VOSviewer software to conduct network analyses for the following reasons: (1) it is an easy-to-use tool, (2) it allows to visualize large networks and present clearly the results, (3) it incorporates three types of visualizations: network visualization, overlay visualization, and density visualization, (4) it offers distance-based visualization in which the nodes' distance infers their relatedness (van Eck \& Waltman, 2014), and (5) it helps in visualizing the outputs through various bibliometric metrics (Merigó et al., 2018).

\subsection{Co-word analysis}

Co-word analysis is a content analysis method that captures scientific maps of a field using the document's keywords. This aims to identify words with high frequencies to extract the 
concept and co-occurrence relationship behind. We identified 19,489 unique keywords. With such large number, it is difficult to get a clear map of the most important keywords. According to Chai and Xiao (2012), only the most frequent keywords offer a deep understanding of key topics, and therefore, keywords should be limited. Thus, we use a threshold of at least 5 as a minimum co-occurrence frequency. As a result, 1,796 unique keywords meet this threshold and were used for the analysis.

Figure 3 represents a density view map of keywords. Three main colours can be easily figured out: green, yellow and warm red. Green reflects lower density keywords, yellow reflects medium density keywords, and warmer red reflects the highest density keywords representing the hot themes. As the distance increases from the centre of gravity, the colour automatically changes, demonstrating that they are far from hot themes and the integrated clusters will be changed to non-integrated ones. Results of the analysis reveal four well-separated subfields in KM research: "knowledge management" (middle left), "performance" (middle right), "innovation" (lower middle) and "knowledge sharing" (upper middle) (Figure 3). Meanwhile, "knowledge management", "performance", "innovation", "knowledge sharing", "management", "knowledge transfer", "model", "firm" and "impact", and "absorptive-capacity" emerge as main keywords with 2,032, 1,465, 1,244, 1,109, 1,085, 760, 719, 582, 581, and 553 occurrence frequency, respectively.

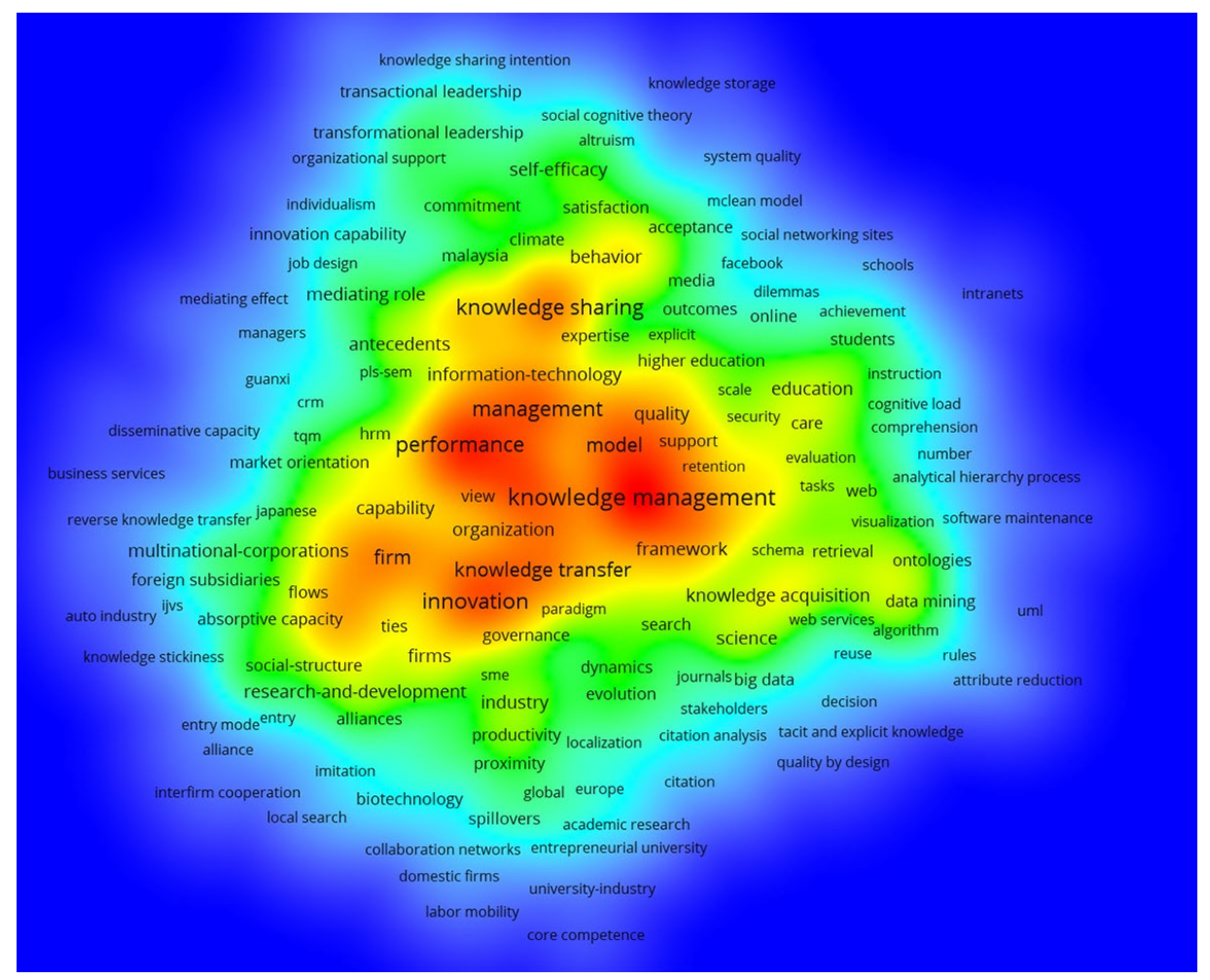

Figure 3. Co-word analysis of keywords: heat map 


\subsection{Co-citation analysis}

Co-citation analysis was introduced by Small (1973) and, since then, it has gained great popularity in the bibliometric research. This evaluates the degree of correlation between papers or authors. Papers/authors are co-cited if they appear together in the reference list of other papers. Most often co-cited papers/authors represent similar research topics/interests that were mostly discussed in the literature.

\subsubsection{Co-citation analysis of cited references}

In this study, we had a dataset of 230,653 cited articles. According to McCain (1990), when the dataset is too large, it is possible to establish a threshold in terms of minimum number of citations received by papers to identify the most influential contributions in a given field. Considering 150 as the minimum number of citations of a cited reference, 77 papers meet this threshold and, therefore, they were included in the analysis (Table 7). Figure 3 shows the co-citation network structure of the cited references.

Table 7. Clustering resulting for the most cited references

\begin{tabular}{|c|c|c|c|}
\hline \multicolumn{2}{|c|}{$\begin{array}{c}\text { Cluster } 1 \\
\begin{array}{l}\text { Knowledge sharing and knowledge } \\
\text { sharing networks }\end{array}\end{array}$} & \multicolumn{2}{|c|}{$\begin{array}{c}\text { Cluster } 2 \\
\text { Knowledge creation, Organizational capabilities, } \\
\text { innovation, and KM }\end{array}$} \\
\hline $\begin{array}{l}\text { - Argote et al. (2000) } \\
\text { - Argote and Ingram (2000) } \\
\text { - Argote et al. (2003) } \\
\text { - Cohen and Levinthal (1990) } \\
\text { - Dyer and Singh (1998) } \\
\text { - Dyer and Nobeoka (2000) } \\
\text { - Gupta and Govindarajan } \\
\text { (2000a) } \\
\text { - Gupta and Govindarajan } \\
\text { (2000b) } \\
\text { - Hamel (1991) } \\
\text { - Hansen (2002) } \\
\text { - Inkpen and Tsang (2005) } \\
\text { - Kogut and Zander (1992) } \\
\text { - Kogut and Zander (1993) } \\
\text { - Kogut and Zander (1996) } \\
\text { - Lane and Lubatkin (1998) } \\
\text { - Levin and Cross (2004) }\end{array}$ & $\begin{array}{l}\text { - } \text { Mowery et al. (1996) } \\
\text { - Nahapiet and Ghoshal } \\
\text { (1998) } \\
\text { - Powell et al. (1996) } \\
\text { - Reagans and McEvily } \\
\text { (2003) } \\
\text { - Simonin (1999) } \\
\text { - Szulanski (1996) } \\
\text { - Szulanski (2000) } \\
\text { - Tsai (2001) } \\
\text { - Tsai and Ghoshal (1998) } \\
\text { - Uzzi (1977) } \\
\text { - Yli-renko et al. (2001) } \\
\text { - Zahra and George (2002) } \\
\text { - Zander and Kogut (1995) }\end{array}$ & $\begin{array}{l}\text { - Alavi and Leidner (2001) } \\
\text { - Barney (1991) } \\
\text { - Brown and Duguid (1991) } \\
\text { - Brown and Duguid (2001) } \\
\text { - Cook and Brown (1999) } \\
\text { - Davenport and Prusak } \\
\text { (1998) } \\
\text { - Davenport et al. (1998) } \\
\text { - Gold et al. (2001) } \\
\text { - Grant (1996) } \\
\text { - Hansen (1999) } \\
\text { - Huber (1991) } \\
\text { - Lee and Choi (2003) } \\
\text { - Leonard-Barton (1991) } \\
\text { - March (1991) }\end{array}$ & $\begin{array}{l}\text { - Nelson and } \\
\text { Winter (1982) } \\
\text { - Nonaka (1991) } \\
\text { - Nonaka (1995). } \\
\text { - Nonaka and } \\
\text { Konno (1998) } \\
\text { - Nonaka et al. } \\
\text { (2000) } \\
\text { - Polanyi (1966) } \\
\text { - Spender (1996) } \\
\text { - Teece et al. (1997) } \\
\text { - Von Krogh (1998) } \\
\text { - Wenger (1998) } \\
\text { - Wernerfelt (1984) } \\
\text { - Zack (1999) }\end{array}$ \\
\hline \multicolumn{4}{|c|}{$\begin{array}{c}\text { Cluster } 3 \\
\text { Barriers, motivations and stages of knowledge sharing }\end{array}$} \\
\hline $\begin{array}{l}\text { - Bock et al. (2005) } \\
\text { - Cabrera and Cabrera (2002) } \\
\text { - Cabrera et al. (2006) } \\
\text { - Cabrera and Cabrera (2005) } \\
\text { - Chiu et al. (2006) } \\
\text { - Cummings (2004) } \\
\text { - Davenport and Klahr (1998) } \\
\text { - De Long and Fahey (2000) } \\
\text { - Hendriks (1999) } \\
\text { - Hsu et al. (2007) } \\
\text { - Ipe (2003) }\end{array}$ & & $\begin{array}{l}\text { - Kankanhalli et al. (2005) } \\
\text { - Lin (2007a) } \\
\text { - Lin (2007b) } \\
\text { - McDermott and O’Dell (20 } \\
\text { - O’Dell and Grayson (1998) } \\
\text { - Osterloh and Frey (2000) } \\
\text { - Riege (2005) } \\
\text { - Van Den Hooff and De Rid } \\
\text { - Wang and Noe (2010) } \\
\text { - Wasko and Faraj (2000) } \\
\text { - Wasko and Faraj (2005) }\end{array}$ & 1) \\
\hline
\end{tabular}




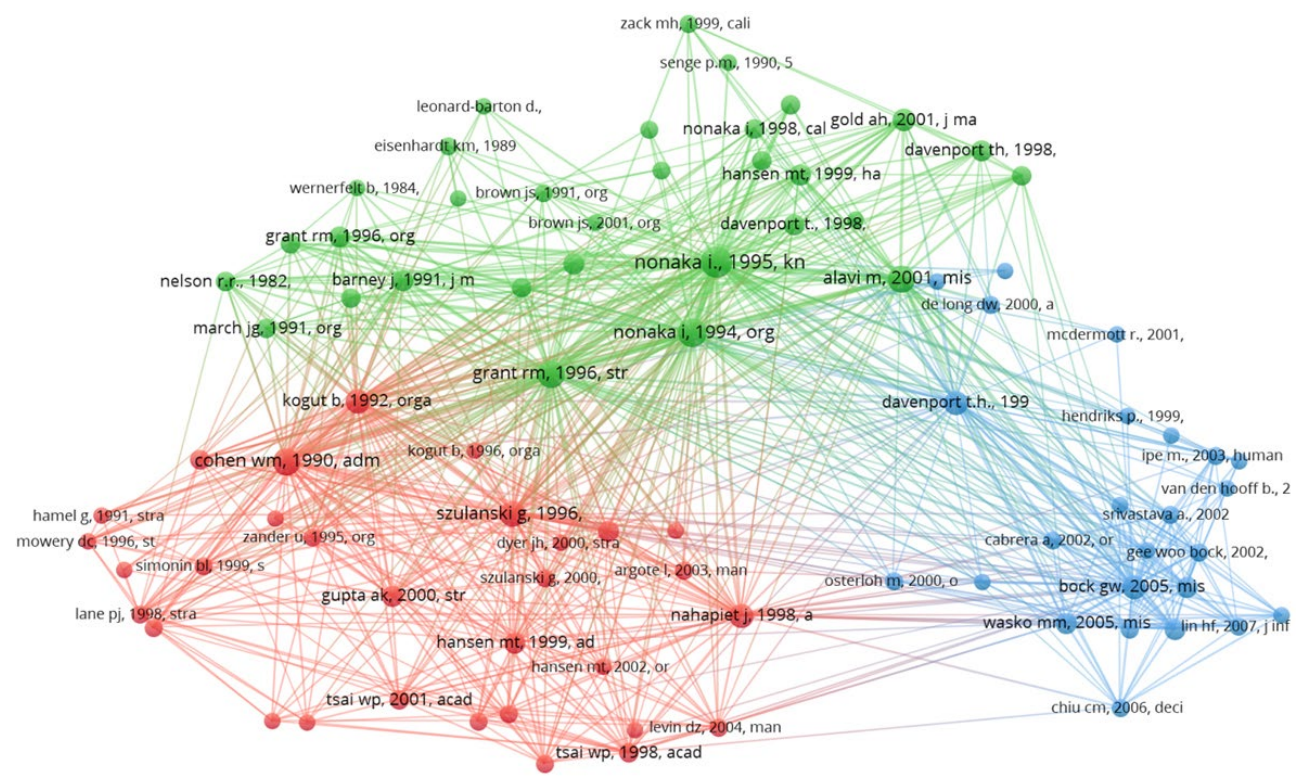

Figure 4. Articles' co-citation analysis

Figure 4 shows three different clusters depicting different topic areas and offering a direct view of the relationship among the papers. The first cluster includes red nodes. We named this cluster as "KM frameworks". The second cluster includes green nodes and has been defined as "Organizational capabilities, innovation, and KM". "The knowledge-creating company: How Japanese companies create the dynamics of innovations" published by Nonaka and Takeuchi (1995) and "A dynamic theory of organizational knowledge creation" published by Nonaka (1994) appeared as the most cited articles and they belong to this cluster. "The knowledge-creating company: How Japanese companies create the dynamics of innovations" published by Nonaka and Takeuchi (1995) and "Toward a knowledge-based theory of the firm" published by Grant (1996) emerge as secondly highly co-cited articles.

The last cluster includes blue nodes and has been named as "Barriers, motivations, and stages of knowledge sharing". Meanwhile, Cluster 1 (red cluster) includes papers related to knowledge sharing and knowledge sharing networks. Szulanski (2000) proposed a model that discusses the knowledge transfer stages and difficulties that firms face at different stages of the knowledge transfer process. Yli-renko et al. (2001) confirmed the mediating role of knowledge acquisition between social capital and the exploitation of knowledge. Hansen (2002) introduced the knowledge networks concept to explain effective knowledge sharing in multiunit companies. Powell et al. (1996) defined inter-organizational collaboration as a network of learning. Gupta and Govindarajan (2000b) analyzed the process of knowledge transfer, whereas Inkpen and Tsang (2005) evaluated how networks' social capital dimensions impact knowledge transfer. Likewise, Levin and Cross (2004) proposed and tested a framework for knowledge transfer. Lane and Lubatkin (1998) studied the role of a partner's knowledge and research networks in the inter-organizational learning context, whereas Mowery et al. 
(1996) emphasized on the inter-firm knowledge sharing among strategic business partners. Nevertheless, the way how knowledge is shared depends upon the competence of the multinational organizations in transferring knowledge to other firms (Kogut \& Zander, 1993), and the positive effect of interaction between absorptive capacity and network position on a firm's performance has utmost importance (Tsai, 2001). In the same vein, network range and the strength of network ties impact the knowledge transfer process (Reagans \& McEvily, 2003). Furthermore, few researchers emphasized that firms should extend their dynamic learning capability beyond their knowledge creation networks to attain unique competitive edge (Dyer \& Nobeoka, 2000). On the other hand, research also claimed that not all business partners are equally important for knowledge creation and transfer (Hamel, 1991). Also, the firms need to put more effort into identifying knowledge than in understanding how to create, retain and share knowledge (Argote et al., 2003). Kogut and Zander (1992) provided an overview of the relationship between the firm's knowledge, combinative capabilities, and the replication of technology.

Cluster 2 (green cluster) includes papers dealing with knowledge creation, organizational capabilities, innovation, and KM. Researchers have further established the relationships between different factors of KM (Lee \& Choi, 2003). Nonaka (1994) emphasized that organizational knowledge creation is a wide-spread and dynamic concept whose effectiveness depends upon the balance between explicit and tacit knowledge. Meanwhile, few researchers reported explicit, tacit, individual and group knowledge as four sources of organizational knowledge creation (Cook \& Brown, 1999; Brown \& Duguid, 2001). Other researchers claimed organization culture and identity, routines, policies and systems, documents, and employees (Grant, 1996) cognitive and behavioral dimensions as multiple ways of knowledge creation (Huber, 1991). Similarly, a knowledge creation model is proposed including three components: SECI process, $\mathrm{Ba}$ (the shared context for knowledge creation), and knowledge assets (Nonaka et al., 2000). The organizations can obtain and share knowledge considering other means, comprising, declarative, causal, relational, and conditional (Zack, 1999). A disproportionate emphasis either on exploitation or exploration can hamper the business performance (March, 1991). Besides, Nonaka (1991) discussed the notion of "tacit" knowledge as well as valuable and subjective information that are difficult to create and share. Davenport and Prusak (1998) underlined the cultural and behavioral concerns and effective ways to incorporate information technology for KM. Evidence is also available that supports a positive link between information technology and organizational KM (Alavi \& Leidner, 2001). Gold et al. (2001) reported the perspectives of effective KM under organizational capabilities. The literature further supported the relationships between work, learning, and innovation (Brown \& Duguid, 1991), and established the association between different factors of KM (Lee \& Choi, 2003).

Cluster 3 (blue cluster) includes paper dealing with barriers, motivations, and stages of knowledge sharing. Osterloh and Frey (2000) and Lin (2007a) explained the effect of different types of extrinsic and intrinsic motivations related to explicit and tacit knowledge sharing intentions. Similarly, extrinsic motivators, social-psychological drivers and organizational climate influence individuals' knowledge sharing intentions (Bock et al., 2005). However, the employees share their knowledge in the case when they consider that it will enhance their professional goodwill (Wasko \& Faraj, 2005) as individual and organizational factors signifi- 
cantly affect the willingness of the employees to collect and share knowledge and fosters the innovative capacity of firms (Lin, 2007b). On the other hand, Hsu et al. (2007) proposed a social cognitive theory-based framework that comprises knowledge exchange self-efficacy and outcome. Meanwhile, the research concluded that external knowledge sharing is more strongly related to performance in the case where workgroups are more structurally diverse (Cummings, 2004). Van den Hooff and van Weenen (2004) emphasized that to differentiate the different knowledge exchange processes, the levels of commitment and knowledge exchange, and modes of computer-mediated communication have immense importance to explain the relationship between commitment, knowledge exchange, and computer-mediated communication use. However, resource availability impacts electronic knowledge repositories usage for knowledge search mainly during the low task tacitness is low (Kankanhalli et al., 2005). Ipe (2003) highlighted the interconnection between the type of knowledge, sharing intention, sharing opportunities, and the work culture.

\subsubsection{Co-citation analysis of authors}

As co-citations of authors are concerned, there were a total of 121,322 different authors cited within the sample articles. We considered the threshold of 250 citations received by an author and only 75 met this condition (Table 8 ). This analysis reveals that "Nonaka and Grant" are two highly co-cited authors in the KM literature, which are further followed by "Nonaka and Davenport"; "Nonaka and Polanyi" and "Grant and Alavi". Figure 5 reports the authors' co-citation network. The analysis classified 75 researchers into 3 clusters: cluster 1 (red nodes), cluster 2 (green nodes), and cluster 3 (blue nodes). Meanwhile, the thickness of the link indicates the strength of co-citations ties.

Cluster 1 comprises researchers focusing on strategic alliances, organizational capabilities, and knowledge transfer. In this context, Robert M. Grant evaluates the coordination systems by which organizations integrate their employees' knowledge. Walter W. Powell's expertise is in inter-organizational collaborations to access and manage knowledge. Anil K. Gupta explores knowledge outflows from a subsidiary and knowledge inflows into a subsidiary and their related associations. David J. Teece analyses development of dynamic capabilities for knowledge management. Udo Zander's expertise concerns the transfer and imitation of the firm's capabilities. Linda Argote's expertise is in knowledge transfer and its mechanisms across organizations. Further, Cross Rob's expertise is in enhancing employees' capability to create and exchange knowledge in social networks. Bernard L. Simonin and David C. Mowery investigate the strategic process of knowledge transfer within strategic alliances. Ranjay Gulati focuses on social structure and strategic alliance formulation among patterns. Other researchers investigate inter-partner learning within a strategic alliance (Bruce Kogut; Gary Hamel and Andrew C. Inkpen; Peter J. Lane; Shaker A. Zahra). In addition, James G. March analyses mutual learning and knowledge sharing between members. Richard R. Nelson analyse the relationship between mutual trust, shared knowledge and information system performance.

Cluster 2 includes researchers specialized in knowledge creation and management practices. Spender John Christopher explores knowledge management processes inside and outside the organizational boundaries. Herbert A. Simon investigates the processes of acquisition 
Table 8. Clustering resulting for the most cited authors

\begin{tabular}{|c|c|c|c|}
\hline \multicolumn{2}{|c|}{$\begin{array}{c}\text { Cluster } 1 \\
\text { Strategic alliance, organizational capabilities, } \\
\text { and knowledge transfer }\end{array}$} & \multicolumn{2}{|c|}{$\begin{array}{c}\text { Cluster } 2 \\
\text { Knowledge creation and management } \\
\text { practices }\end{array}$} \\
\hline $\begin{array}{l}\text { - Argote, I. } \\
\text { - Barney, J. } \\
\text { - Burt, R. S. } \\
\text { - Cohen, W. M. } \\
\text { - Cross, R. } \\
\text { - Eisenhardt, K. M. } \\
\text { - Grant, R. M. } \\
\text { - Gulati, R. } \\
\text { - Gupta, A. K. } \\
\text { - Hamel, G. } \\
\text { - Hansen, M. T. } \\
\text { - Inkpen, A. C. } \\
\text { - Kogut, B. } \\
\text { - Lane, P. J. }\end{array}$ & $\begin{array}{l}\text { - Levin, D. Z. } \\
\text { - March, J. G. } \\
\text { - Mowery, D. C. } \\
\text { - Nahapiet, J. } \\
\text { - Nelson, R. R. } \\
\text { - Powell, W. W. } \\
\text { - Reagans, R. } \\
\text { - Simonin, B. L. } \\
\text { - Szulanski, G. } \\
\text { - Teece, D. J. } \\
\text { - Tsai, W. P. } \\
\text { - Uzzi, B. } \\
\text { - Zahra, S. A. } \\
\text { - Zander, U. }\end{array}$ & $\begin{array}{l}\text { - Alavi, M. } \\
\text { - Argyris, C. } \\
\text { - Bontis, N. } \\
\text { - Brown, J. S. } \\
\text { - Draft, R. L. } \\
\text { - Davenport, T. H. } \\
\text { - Drucker, P. F. } \\
\text { - Holsapple, C. W. } \\
\text { - Huber, G. P. } \\
\text { - Lave, J. } \\
\text { - Liebowitz, J. } \\
\text { - Mcdermott, R. } \\
\text { - Nonaka, I., } \\
\text { - O’Dell, C. } \\
\text { - Orlikowski, W. J. }\end{array}$ & $\begin{array}{l}\text { - Polanyi, M. } \\
\text { - Prahalad, C. K. } \\
\text { - Senge, P. M. } \\
\text { - Serenko, A. } \\
\text { - Simon, H. A. } \\
\text { - Spender, J. C } \\
\text { - Sveiby, K. E. } \\
\text { - Tiwana, A. } \\
\text { - Tsoukas, H. } \\
\text { - Von Krogh, G. } \\
\text { - Weick, K. E. } \\
\text { - Wenger, E. } \\
\text { - Wiig, K. M. } \\
\text { - Yin, R. K. } \\
\text { - Zack, M. H. }\end{array}$ \\
\hline \multicolumn{4}{|c|}{$\begin{array}{l}\text { Cluster } 3 \\
\text { Factors affect knowledge transfer and organizational performance }\end{array}$} \\
\hline $\begin{array}{l}\text { - Amabile, T. M. } \\
\text { - Ardichvili, A. } \\
\text { - Bock, G. W. } \\
\text { - Cabrera, A. }\end{array}$ & $\begin{array}{l}\text { - Chen, C. J. } \\
\text { - Chin, W. W. } \\
\text { - Darroch, J. } \\
\text { - Foss, N. J. }\end{array}$ & $\begin{array}{l}\text { - Gold, A. H. } \\
\text { - Jarvenpaa, S. L. } \\
\text { - Kankanhalli, A. } \\
\text { - Liao, S. H. }\end{array}$ & $\begin{array}{l}\text { - Lin, H. F. } \\
\text { - Srivastava, A. } \\
\text { - Van den Hoof, B. } \\
\text { - Wang, S. } \\
\text { - Wasko, M. M. }\end{array}$ \\
\hline
\end{tabular}

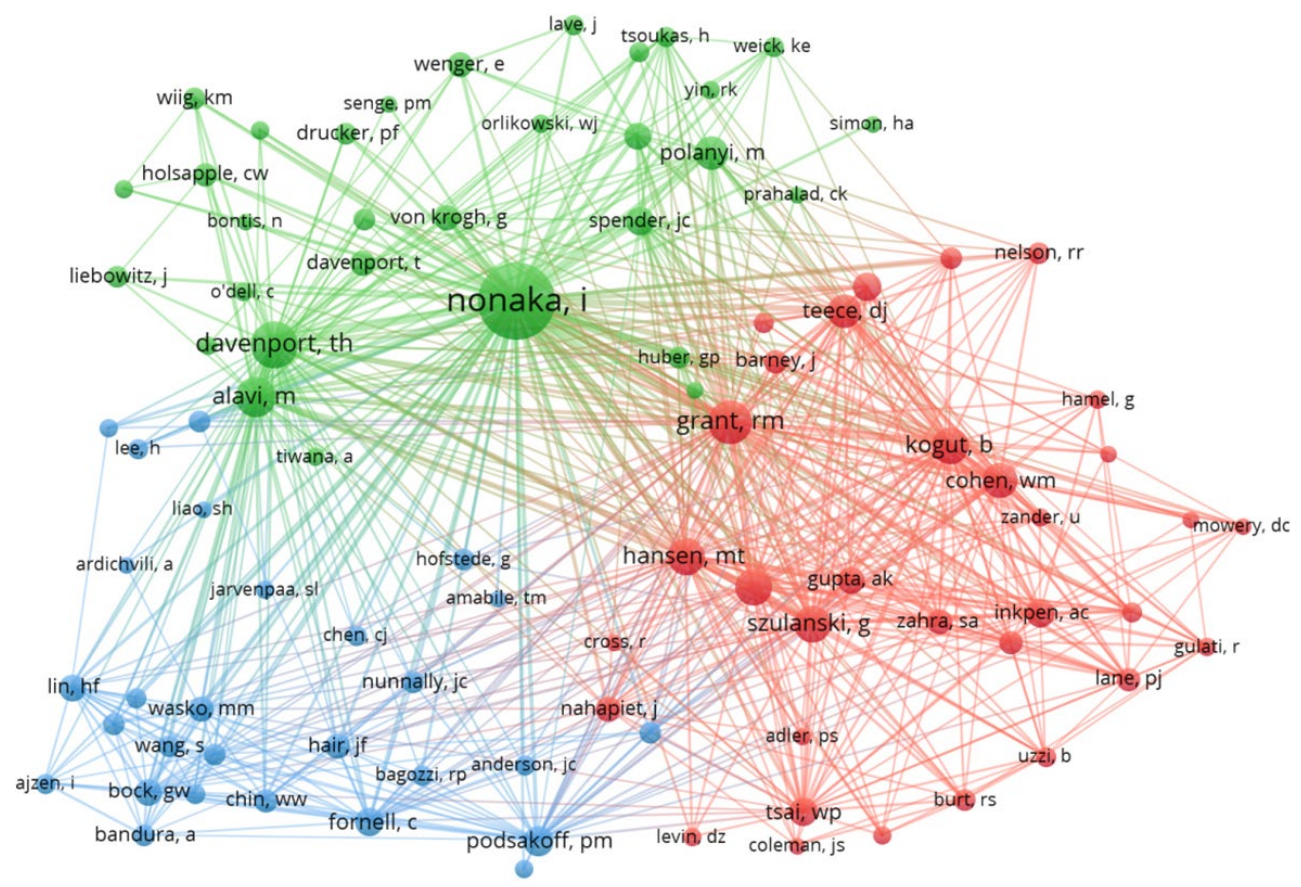

Figure 5. Authors' co-citation analysis 
and integration of external knowledge of the employees. Meanwhile, Michael Polanyi focuses on the key role of tacit knowledge as a source of all types of knowledge. Ikujiro Nonaka and Haridimos Tsoukas examine the knowledge creation process through the mutual conversion of tacit and explicit knowledge and visionary leadership. Jean Lave and Etienne Wenger highlight the key role of participation in social practices as a knowledge creation practice. Thomas $\mathrm{H}$. Davenport expertise is in knowledge capturing, managing customer knowledge and its reuse. Few researchers investigate how a collaborative environment motivates the employees to learn (Karl-Erik Sveiby) and accordingly improves their productivity (Peter F. Drucker). Likewise, Alexander Serenko investigates the relationship between intellectual capital and KM, whereas Holsapple C.W. underlines the necessity of managerial and environmental factors for knowledge creation and successful KM. Prahalad C.K demonstrates the importance of core competencies (e.g., collective knowledge of the company about skills, technologies, and new markets) for effective KM. Maryam Alavi and George P. Huber propose a decision support system for knowledge creation, distribution, information interpretation and application of knowledge in organizational, and KM research issues. Georg von Krogh focus the attention on the role of leadership and communal resources in knowledge creation and sharing processes. Chris Argyris discusses KM theories related to action and learning. Further, in this cluster, Likewise, Jay Liebowitz propose to measure intellectual capital through KM metrics.

Cluster 3 involves researchers investigating the factors affecting knowledge transfer and organizational performance. In this line, Chung-Jen Chen investigates the impact of human capital, organizational capital, relational capital, and knowledge sharing. Sirkka L. Jarvenpaa focuses on reporting the impact of organizational information ownership, propensity to share information, task interdependence, computer comfort, and characteristics related to computer-based information to use collaborative electronic media for knowledge creation and sharing. Meanwhile, Alexandre Ardichvili explores the role of online learning, KM and knowledge sharing in virtual communities. Cabrera Ángel studies knowledge-sharing dilemmas and determinants of individual engagement in knowledge sharing. Li-Fen Liao illustrates the influence of managers' social power and mutual trust on employees' knowledge-sharing behaviour. In this cluster, other researchers depict the impact of rewards systems, leadership (Srivastava Abhishek), and behavioural intention on knowledge sharing (Gee-Woo Bock). On the other hand, Atreyi Kankanhalli highlights the factors affecting electronic knowledge repositories usage for knowledge seeking. Further, Nicolai J. Foss illustrates the role of internal knowledge, network knowledge, and cluster knowledge on knowledge transfer, and Andrew $\mathrm{H}$. Gold examines the impact of knowledge infrastructure capability and knowledge process capability on organizational performance. Jenny Darroch developed measures of KM behaviours, and implementation of the same to foster innovation and organizational performance.

\section{Discussion, implications and conclusions}

This paper conducts a bibliometric overview of KM literature using the WoS database. The paper also visualizes the bibliometric networks for citations, keywords, and co-authorship patterns. There have been a good number of papers published in the KM domain over the years, many of them in the last decade. However, despite few good studies on KM have been 
reported in the last few years, a detailed bibliometric and network analysis to systematically and objectively recognize principal contributions, authors and growing research clusters have not been performed yet. This paper contributes to the body of knowledge by providing a comprehensive overview of KM literature in this way.

From the analysis, it can be concluded that research on KM has attained increasing attention and emerges as a popular research field. Totally 8,721 papers on KM were collected and analysed using bibliometric and network analysis. The papers over the time indicate that 6,413 papers published between 2008 and 2019 represent $73.53 \%$ of total identified papers. Meanwhile, all the most cited articles are published before 2010. This is not surprising as the field started growing. The research works published in the last 5-6 years have not had the opportunity to receive as much pull as citations have yet to accumulate.

As journals' contribution is concerned, 2,353 journals have contributed to a total of 8,721 articles. The top 25 journals together contributed with 1,930 papers representing the $22.13 \%$ of total identified papers. Journal of Knowledge Management and Knowledge Management Research \& Practiceare the two top journals in terms of papers published, whereas Journal of Knowledge Managementand Strategic Management Journal are the two top-cited journals.

The United States and United Kingdom are the most productive continents. Besides, the contribution of South Africa and Asian is quite less. The University of Illinois and National University of Singaporetook the leading position of organizations in average citations per article. Analysis proved an important approach to highlight hotspot research areas. The results confirm four hotspots, namely, knowledge management, performance, innovation, and knowledge sharing.

This study gives a noteworthy contribution to the body-of-knowledge on KM while broadening prior reviews (Kuah \& Wong, 2011; Asrar \& Anwar, 2016; Cerchione et al., 2020) in different ways. First, the present study applies bibliometric and network approaches to uncover the most influential articles, scholars, institutions, and countries as per the number of articles published and citations. Second, it proposes three clusters of co-cited articles namely knowledge sharing and knowledge sharing networks, knowledge creation, organizational capabilities, innovation and KM, and barriers, motivations and stages of knowledge sharing. Third, it proposed three clusters of co-cited authors such as strategic alliance, organizational capabilities and knowledge transfer, knowledge creation and management practices, and factors affecting knowledge transfer and organizational performance. Fourth, the study supports researchers to underline the most influential articles. Fifth, the findings can assist the industries and governments to identify the main research and development centres working in the field of KM for research projects. Sixth, editors organizing special and regular issues on the topic can invite leading authors and institutions. Finally, compared to prior qualitative literature reviews, the present study offers a more rigorous, updated, and detailed outline of research on KM. This study builds on and extends the previous contributions offering a broader framework for guiding scholars approaching KM from diverse perspectives and more meaningful viewpoints. The clustering of co-citations based articles will guide the scholars to identify the research gaps and further purse the research to enrich the KM literature. Scholars working on KM domain may easily recognize the researchers, research institutions and countries paying attention in the KM areas. Thus, interested scholars can 
perform joint research projects, share their ideas and results as well as apply for academic positions to further investigate the mentioned field.

As the managerial contribution is concerned, the present study offers opportunities to the practitioners and organizations engaged in KM. The study further provides managers with diverse outlooks that enable them to enjoy the benefits of KM in their work. The bibliometric information about the KM literature has immense value for managers as it enables them to spot the KM expertise globally. Accordingly, the research projects on KM can be developed considering this information.

Although this article significantly contributes to the field of KM, nevertheless this study is not without limitations. Few journals on the KM are not yet covered by WoS. Hence, several other major databases can be considered (e.g., Scopus, EBSCO and Google Scholar) in their future research. Second, we included only research articles and review articles; therefore, the inclusion of other types of documents may lead toward different conclusions. Thirdly, we performed the co-citation analysis using network analysis and VOSviewer software. However, other methods and software may be used, such as Gephi. Lastly, the bibliometric analysis in the present study focuses on the general themes of KM processes, and not restricted to KM up to particular topic. Therefore, in future, it would be interesting to provide the bibliometric overview of KM literature analysing the logical intersection with crucial topics affecting the industrial environment (e.g., sustainability, circular economy, and Industry 4.0).

\section{Author contributions}

Authors equally contributed to the paper.

\section{Disclosure statement}

No disclosure statements and conflicts of interest have to be declared.

\section{References}

Abbas, J., \& Sağsan, M. (2019). Impact of knowledge management practices on green innovation and corporate sustainable development: A structural analysis. Journal of Cleaner Production, 229, 611620. https://doi.org/10.1016/j.jclepro.2019.05.024

Alavi, M., \& Leidner, D. E. (2001). Knowledge management and knowledge management systems: Conceptual foundations and research issues. MIS Quarterly, 25(1), 107-136. https://doi.org/10.2307/3250961

Alexandru, V. A., Bolisani, E., Andrei, A. G., Cegarra-Navarro, J. G., Martínez Martínez, A., Paiola, M., Scarso, E., Vătămănescu, E.-M., \& Zieba, M. (2019). Knowledge management approaches of small and medium-sized firms: A cluster analysis. Kybernetes, 49(1), 73-87. https://doi.org/10.1108/K-03-2019-0211

Argote, L., \& Ingram, P. (2000). Knowledge transfer: A basis for competitive advantage in firms. Organizational Behavior and Human Decision Processes, 82(1), 150-169. https://doi.org/10.1006/obhd.2000.2893

Argote, L., McEvily, B., \& Reagans, R. (2003). Managing knowledge in organizations: An integrative framework and review of emerging themes. Management Science, 49(4), 571-582.

https://doi.org/10.1287/mnsc.49.4.571.14424 
Asiaei, K., \& Bontis, N. (2019). Translating knowledge management into performance: The role of performance measurement systems. Management Research Review, 43(1), 113-132. https://doi.org/10.1108/MRR-10-2018-0395

Asrar, M., \& Anwar, S. (2016). A systematic review of knowledge management and knowledge sharing: Trends, issues, and challenges. Cogent Business \& Management, 3(1), 1-17. https://doi.org/10.1080/23311975.2015.1127744

Barney, J. B. (1991). Firm resources and sustained competitive advantage. Journal of Management, 17(1), 99-120. https://doi.org/10.1177/014920639101700108

Bock, G. W., Zmud, R. W., Kim, Y. G., \& Lee, J. N. (2005). Behavioral intention formation in knowledge sharing: Examining the roles of extrinsic motivators, social-psychological factors, and organizational climate. MIS Quarterly, 29(1), 87-111. https://doi.org/10.2307/25148669

Brown, J. S., \& Duguid, P. (1991). Organizational learning and communities-of-practice: Toward a unified view of working, learning, and innovation. Organization Science, 2(1), 40-57. https://doi.org/10.1287/orsc.2.1.40

Brown, J. S., \& Duguid, P. (2001). Knowledge and organization: A social-practice perspective. Organization Science, 12(2), 198-213. https://doi.org/10.1287/orsc.12.2.198.10116

Buckley, P. J., \& Carter, M. J. (1999). Managing cross-border complementary knowledge. International Studies of Management and Organization, 29(1), 80-104. https://doi.org/10.1080/00208825.1999.11656758

Buckova, B. (2017). Corporate culture as an important factor in the implementation of knowledge management. AD ALTA: Journal of Interdisciplinary Research, 7(2), 36-39.

Buenstorf, G., \& Costa, C. (2018). Drivers of spin-off performance in industry clusters: Embodied knowledge or embedded firms? Research Policy, 47(3), 663-673. https://doi.org/10.1016/j.respol.2018.01.015

Cabrera, A., \& Cabrera, E. F. (2002). Knowledge-sharing dilemmas. Organization Studies, 23(5), 687710. https://doi.org/10.1177/0170840602235001

Cabrera, A., Collins, W. C., \& Salgado, J. F. (2006). Determinants of individual engagement in knowledge sharing. The International Journal of Human Resource Management, 17(2), 245-264. https://doi.org/10.1080/09585190500404614

Cabrera, E. F., \& Cabrera, A. (2005). Fostering knowledge sharing through people management practices. International Journal of Human Resource Management, 16(5), 720-735. https://doi.org/10.1080/09585190500083020

Cardoni, A., Zanin, F., Corazza, G., \& Paradisi, A. (2020). Knowledge management and performance measurement systems for SMEs' economic sustainability. Sustainability (Switzerland), 12(7), 2594. https://doi.org/10.3390/su12072594

Castagna, F., Centobelli, P., Cerchione, R., Esposito, E., Oropallo, E., \& Passaro, R. (2020). Customer knowledge management in SMEs facing digital transformation. Sustainability, 12(9), 3899. https://doi.org/10.3390/su12093899

Centobelli, P., Cerchione, R., Esposito, E., \& Shashi. (2019). The mediating role of knowledge exploration and exploitation for the development of an entrepreneurial university. Management Decision, 57(12), 3301-3320. https://doi.org/10.1108/MD-11-2018-1240

Cerchione, R., Centobelli, P., Zerbino, P., \& Anand, A. (2020). Back to the future of Knowledge Management Systems off the beaten paths. Management Decision, 58(9), 1953-1984. https://doi.org/10.1108/MD-11-2019-1601

Chai, K., \& Xiao, X. (2012). Understanding design research: A bibliometric analysis of design studies (1996-2010). Design Studies, 33(1), 24-43. https://doi.org/10.1016/j.destud.2011.06.004

Chiu, C. M., Hsu, M. H., \& Wang, E. T. (2006). Understanding knowledge sharing in virtual communities: An integration of social capital and social cognitive theories. Decision Support Systems, 42(3), 1872-1888. https://doi.org/10.1016/j.dss.2006.04.001 
Cohen, W. M., \& Levinthal, D. A. (1990). Absorptive capacity: A new perspective on learning and innovation. Administrative Science Quarterly, 35(1), 128-152. https://doi.org/10.2307/2393553

Cook, S. D., \& Brown, J. S. (1999). Bridging epistemologies: The generative dance between organizational knowledge and organizational knowing. Organization Science, 10(4), 381-400. https://doi.org/10.1287/orsc.10.4.381

Cummings, J. N. (2004). Work groups, structural diversity, and knowledge sharing in a global organization. Management Science, 50(3), 352-364. https://doi.org/10.1287/mnsc.1030.0134

Davenport, T. H., De Long, D. W., \& Beers, M. C. (1998). Successful knowledge management projects. Sloan Management Review, 39(2), 43-57.

Davenport, T. H., \& Klahr, P. (1998). Managing customer support knowledge. California Management Review, 40(3), 195-208. https://doi.org/10.2307/41165950

Davenport, T. H., \& Prusak, L. (1998). Working knowledge: How organizations manage what they know. Harvard Business Press.

De Long, D. W., \& Fahey, L. (2000). Diagnosing cultural barriers to knowledge management. Academy of Management Perspectives, 14(4), 113-127. https://doi.org/10.5465/ame.2000.3979820

Durst, S., Hinteregger, C., \& Zieba, M. (2019). The linkage between knowledge risk management and organizational performance. Journal of Business Research, 105, 1-10. https://doi.org/10.1016/j.jbusres.2019.08.002

Dyer, J. H., \& Nobeoka, K. (2000). Creating and managing a high-performance knowledge-sharing network: The Toyota case. Strategic Management Journal, 21(3), 345-367. https://doi.org/10.1002/(SICI)1097-0266(200003)21:3<345::AID-SMJ96>3.0.CO;2-N

Dyer, J. H., \& Singh, H. (1998). The relational view: Cooperative strategy and sources of interorganizational competitive advantage. Academy of Management Review, 23(4), 660-679. https://doi.org/10.5465/amr.1998.1255632

Endres, H., Helm, R., \& Dowling, M. (2020). Linking the types of market knowledge sourcing with sensing capability and revenue growth: Evidence from industrial firms. Industrial Marketing Management, 90, 30-43. https://doi.org/10.1016/j.indmarman.2020.06.004

Gold, A. H., Malhotra, A., \& Segars, A. H. (2001). Knowledge management: An organizational capabilities perspective. Journal of Management Information Systems, 18(1), 185-214. https://doi.org/10.1080/07421222.2001.11045669

Grant, R. M. (1996). Prospering in dynamically-competitive environments: Organizational capability as knowledge integration. Organization Science, 7(4), 375-387. https://doi.org/10.1287/orsc.7.4.375

Gupta, A. K., \& Govindarajan, V. (2000a). Knowledge flows within multinational corporations. Strategic Management Journal, 21(4), 473-496. https://doi.org/10.1002/(SICI)1097-0266(200004)21:4<473::AID-SMJ84>3.0.CO;2-I

Gupta, A. K., \& Govindarajan, V. (2000b). Knowledge management's social dimension: Lessons from Nucor Steel. Sloan Management Review, 42(1), 71. https://sloanreview.mit.edu/article/knowledgemanagements-social-dimension-lessons-from-nucor-steel/

Hamel, G. (1991). Competition for competence and interpartner learning within international strategic alliances. Strategic Management Journal, 12(S1), 83-103. https://doi.org/10.1002/smj.4250120908

Hansen, M. T. (1999). The search-transfer problem: The role of weak ties in sharing knowledge across organization subunits. Administrative Science Quarterly, 44(1), 82-111. https://doi.org/10.2307/2667032

Hansen, M. T. (2002). Knowledge networks: Explaining effective knowledge sharing in multiunit companies. Organization Science, 13(3), 232-248. https://doi.org/10.1287/orsc.13.3.232.2771

Hendriks, P. (1999). Why share knowledge? The influence of ICT on the motivation for knowledge sharing. Knowledge \& Process Management, 6, 91-100.

https://doi.org/10.1002/(SICI)1099-1441(199906)6:2<91::AID-KPM54>3.0.CO;2-M 
Holsapple, C. W. (2005). The inseparability of modern knowledge management and computer-based technology. Journal of Knowledge Management, 9(1), 42-52. https://doi.org/10.1108/13673270510582956

Hsu, M. H., Ju, T. L., Yen, C. H., \& Chang, C. M. (2007). Knowledge sharing behavior in virtual communities: The relationship between trust, self-efficacy, and outcome expectations. International Journal of Human-Computer Studies, 65(2), 153-169. https://doi.org/10.1016/j.ijhcs.2006.09.003

Huber, G. P. (1991). Organizational learning: The contributing processes and the literatures. Organization Science, 2(1), 88-115. https://doi.org/10.1287/orsc.2.1.88

Inkinen, H. (2016). Review of empirical research on knowledge management practices and firm performance. Journal of Knowledge Management, 20(2), 230-257. https://doi.org/10.1108/JKM-09-2015-0336

Inkpen, A. C., \& Tsang, E. W. (2005). Social capital, networks, and knowledge transfer. Academy of Management Review, 30(1), 146-165. https://doi.org/10.5465/amr.2005.15281445

Ipe, M. (2003). Knowledge sharing in organizations: A conceptual framework. Human Resource Development Review, 2(4), 337-359. https://doi.org/10.1177/1534484303257985

Jiang, J., Woosnam, K. M., \& Draper, J. (2014). Structural elements of articles and diachronous citation analysis among top-ranking tourism journals (1990-2010). Tourism Management Perspectives, 12, 48-56. https://doi.org/10.1016/j.tmp.2014.06.004

Kaklauskas, A., \& Kanapeckiene, L. (2005). Knozwledge management and "BRITA in PuBs" project [Žinių valdymas ir "BRITA in PuBs" projektas]. Technological and Economic Development of Economy, 11(2), 78-86. https://doi.org/10.3846/13928619.2005.9637685

Kankanhalli, A., Tan, B. C., \& Wei, K. K. (2005). Contributing knowledge to electronic knowledge repositories: An empirical investigation. MIS Quarterly, 29(1), 113-143. https://doi.org/10.2307/25148670

Kogut, B., \& Zander, U. (1992). Knowledge of the firm, combinative capabilities, and the replication of technology. Organization Science, 3(3), 383-397. https://doi.org/10.1287/orsc.3.3.383

Kogut, B., \& Zander, U. (1993). Knowledge of the firm and the evolutionary theory of the multinational corporation. Journal of International Business Studies, 24(4), 625-645.

https://doi.org/10.1057/palgrave.jibs.8490248

Kogut, B., \& Zander, U. (1996). What firms do? Coordination, identity, and learning. Organization Science, 7(5), 502-518. https://doi.org/10.1287/orsc.7.5.502

Kuah, C. T., \& Wong, K. Y. (2011). Knowledge management performance measurement: A review. African Journal of Business Management, 5(15), 6021-6027.

Lane, P. J., \& Lubatkin, M. (1998). Relative absorptive capacity and interorganizational learning. Strategic Management Journal, 19(5), 461-477.

https://doi.org/10.1002/(SICI)1097-0266(199805)19:5<461::AID-SMJ953>3.0.CO;2-L

Lee, H., \& Choi, B. (2003). Knowledge management enablers, processes, and organizational performance: An integrative view and empirical examination. Journal of Management Information Systems, 20(1), 179-228. https://doi.org/10.1080/07421222.2003.11045756

Leonard-Barton, D. (1991). The factory as a learning laboratory (Harvard Business School Working Paper, 92-023).

Levin, D. Z., \& Cross, R. (2004). The strength of weak ties you can trust: The mediating role of trust in effective knowledge transfer. Management Science, 50(11), 1477-1490. https://doi.org/10.1287/mnsc.1030.0136

Lin, H. F. (2007a). A stage model of knowledge management: an empirical investigation of process and effectiveness. Journal of Information Science, 33(6), 643-659. https://doi.org/10.1177/0165551506076395

Lin, H. (2007b). Knowledge sharing and firm innovation capability: an empirical study. International Journal of Manpower, 28(3/4), 315-332. https://doi.org/10.1108/01437720710755272 
Lin, Y. C., \& Ha, N.-H. (2015). The framework for KM implementation in product and service oriented SMEs: Evidence from field studies in Taiwan. Sustainability, 7(3), 2980-3000. https://doi.org/10.3390/su7032980

Lönnqvist, A. (2017). Embedded knowledge management: Towards improved managerial relevance. Knowledge Management Research and Practice, 15(2), 184-191. https://doi.org/10.1057/s41275-017-0053-y

López-Torres, G. C., Garza-Reyes, J. A., Maldonado-Guzmán, G., Kumar, V., Rocha-Lona, L., \& Cherrafi, A. (2019). Knowledge management for sustainability in operations. Production Planning and Control, 30(10-12), 813-826. https://doi.org/10.1080/09537287.2019.1582091

Maghssudipour, A., Lazzeretti, L., \& Capone, F. (2020). The role of multiple ties in knowledge networks: Complementarity in the Montefalco wine cluster. Industrial Marketing Management, 90, 667-678. https://doi.org/10.1016/j.indmarman.2020.03.021

March, J. G. (1991). Exploration and exploitation in organizational learning. Organization Science, 2(1), 71-87. https://doi.org/10.1287/orsc.2.1.71

Mariani, M., \& Borghi, M. (2019). Industry 4.0: A bibliometric review of its managerial intellectual structure and potential evolution in the service industries. Technological Forecasting and Social Change, 149, 119752. https://doi.org/10.1016/j.techfore.2019.119752

McCain, K. W. (1990). Mapping authors in intellectual space: A technical overview. Journal of the American Society for Information Science, 41, 433-443. https://doi.org/10.1002/(SICI)1097-4571(199009)41:6<433::AID-ASI11>3.0.CO;2-Q

McDermott, R., \& O’Dell, C. (2001). Overcoming cultural barriers to sharing knowledge. Journal of Knowledge Management, 5(1), 76-85. https://doi.org/10.1108/13673270110384428

Merigó, J. M., Pedrycz, W., Weber, R., \& de la Sotta, C. (2018). Fifty years of information sciences: A bibliometric overview. Information Sciences, 432, 245-268. https://doi.org/10.1016/j.ins.2017.11.054

Miklosik, A., Evans, N., Hasprova, M., \& Lipianska, J. (2019). Reflection of embedded knowledge culture in communications of Australian companies. Knowledge Management Research and Practice, 17(2), 172-181. https://doi.org/10.1080/14778238.2018.1538602

Mowery, D. C., Oxley, J. E., \& Silverman, B. S. (1996). Strategic alliances and interfirm knowledge transfer. Strategic Management Journal, 17(S2), 77-91. https://doi.org/10.1002/smj.4250171108

Mulet-Forteza, C., Genovart-Balaguer, J., Mauleon-Mendez, E., \& Merigó, J. M. (2019). A bibliometric research in the tourism, leisure and hospitality fields. Journal of Business Research, 101, 819-827. https://doi.org/10.1016/j.jbusres.2018.12.002

Nahapiet, J., \& Ghoshal, S. (1998). Social capital, intellectual capital, and the organizational advantage. Academy of Management Review, 23(2), 242-266. https://doi.org/10.5465/amr.1998.533225

Nelson, R. R., \& Winter, S. G. (1982). An evolutionary theory of economic change. Belknap Press, Cambridge.

Neves, S. M., \& Da Silva, C. E. S. (2016). Risk management applied to Software development projects in incubated technology-based companies: Literature review, classification, and analysis. Gestao $e$ Producao, 23(4), 798-814. https://doi.org/10.1590/0104-530x472-15

Nonaka, I. (1991). The knowledge creating company. Harvard Business Review, 69(6), 96-104.

Nonaka, I. (1994). A dynamic theory of organizational knowledge creation. Organization Science, 5(1), 14-37. https://doi.org/10.1287/orsc.5.1.14

Nonaka, I., \& Konno, N. (1998). The concept of "Ba": Building a foundation for knowledge creation. California Management Review, 40(3), 40-54. https://doi.org/10.2307/41165942

Nonaka, I., \& Takeuchi, H. (1995). The knowledge-creating company: How Japanese companies create the dynamics of innovation. Oxford University Press. 
Nonaka, I., Toyama, R., \& Konno, N. (2000). SECI, Ba and leadership: A unified model of dynamic knowledge creation. Long Range Planning, 33(1), 5-34. https://doi.org/10.1016/S0024-6301(99)00115-6

O'Dell, C., \& Grayson, C. (1998). If only we knew what we know: Identification and transfer of internal best practices. California Management Review, 40, 154-174. https://doi.org/10.2307/41165948

Osterloh, M., \& Frey, B. S. (2000). Motivation, knowledge transfer, and organizational forms. Organization Science, 11(5), 538-550. https://doi.org/10.1287/orsc.11.5.538.15204

Polanyi, M (1958). Personal knowledge: Towards a post-critical philosophy. University of Chicago Press.

Polanyi, M. (1966). The tacit dimension. Doubleday.

Powell, W. W., Koput, K. W., \& Smith-Doerr, L. (1996). Interorganizational collaboration and the locus of innovation: Networks of learning in biotechnology. Administrative Science Quarterly, 41(1), 116-145. https://doi.org/10.2307/2393988

Raudeliūnienė, J., Davidavičienè, V., \& Petrusevičius, R. (2018). Factors influencing knowledge retention process: Case of Lithuanian armed forces. Technological and Economic Development of Economy, 24(3), 1104-1124. https://doi.org/10.3846/20294913.2017.1309598

Reagans, R., \& McEvily, B. (2003). Network structure and knowledge transfer: The effects of cohesion and range. Administrative Science Quarterly, 48(2), 240-267. https://doi.org/10.2307/3556658

Riege, A. (2005). Three-dozen knowledge-sharing barriers managers must consider. Journal of Knowledge Management, 9(3), 18-35. https://doi.org/10.1108/13673270510602746

Simonin, B. L. (1999). Ambiguity and the process of knowledge transfer in strategic alliances. Strategic Management Journal, 20(7), 595-623. https://doi.org/10.1002/(SICI)1097-0266(199907)20:7<595::AID-SMJ47>3.0.CO;2-5

Small, H. (1973). Co-citation in the scientific literature: A new measure of the relationship between two documents. Journal of the American Society for Information Science, 24, 265-269. https://doi.org/10.1002/asi.4630240406

Spender, J. C. (1996). Making knowledge the basis of a dynamic theory of the firm. Strategic Management Journal, 17(S2), 45-62. https://doi.org/10.1002/smj.4250171106

Sulistio, E. R., \& Dianawati, W. (2020). Environmental innovation as mediation: Knowledge management and firm performance. International Journal of Innovation, Creativity and Change, 13(4), 592-609. https://www.ijicc.net/images/vol_13/Iss_4/13455_Sulistio_2020_E_R.pdf

Szulanski, G. (1996). Exploring internal stickiness: Impediments to the transfer of best practice within the firm. Strategic Management Journal, 17(S2), 27-43. https://doi.org/10.1002/smj.4250171105

Szulanski, G. (2000). The process of knowledge transfer: A diachronic analysis of stickiness. Organizational Behavior and Human Decision Processes, 82(1), 9-27. https://doi.org/10.1006/obhd.2000.2884

Teece, D. J., Pisano, G., \& Shuen, A. (1997). Dynamic capabilities and strategic management. Strategic Management Journal, 18(7), 509-533. https://doi.org/10.1002/(SICI)1097-0266(199708)18:7<509::AID-SMJ882>3.0.CO;2-Z

Trujillo, C. M., \& Long, T. M. (2018). Document co-citation analysis to enhance transdisciplinary research. Science Advances, 4(1), e1701130. https://doi.org/10.1126/sciadv.1701130

Tsai, A. (2016). The effects of innovation by inter-organizational knowledge management. Information Development, 32(5), 1402-1416. https://doi.org/10.1177/0266666915603440

Tsai, W. (2001). Knowledge transfer in intraorganizational networks: Effects of network position and absorptive capacity on business unit innovation and performance. Academy of Management Journal, 44(5), 996-1004. https://doi.org/10.2307/3069443

Tsai, W., \& Ghoshal, S. (1998). Social capital and value creation: The role of intrafirm networks. Academy of Management Journal, 41(4), 464-476. https://doi.org/10.2307/257085 
Uzzi, B. (1997). Social structure and competition in interfirm networks: The paradox of embeddedness. Administrative Science Quarterly, 42(1), 35-67. https://doi.org/10.2307/2393808

Van Den Hooff, B., \& De Ridder, J. A. (2004). Knowledge sharing in context: The influence of organizational commitment, communication climate and CMC use on knowledge sharing. Journal of Knowledge Management, 8(6), 117-130. https://doi.org/10.1108/13673270410567675

Van den Hooff, B., \& van Weenen, F. L. (2004). Committed to share: Commitment and CMC use as antecedents of knowledge sharing. Knowledge Process Management, 11(1), 13-24. https://doi.org/10.1002/kpm.187

Van Eck, N. J., \& Waltman, L. (2014). Visualizing bibliometric networks. In Y. Ding, R. Rousseau, \& D. Wolfram (Eds.), Measuring scholarly impact: Methods and practice. Springer. https://doi.org/10.1007/978-3-319-10377-8_13

Von Krogh, G. (1998). Care in knowledge creation. California Management Review, 3, 133-153. https://doi.org/10.2307/41165947

Wang, Q., \& Waltman, L. (2016). Large-scale analysis of the accuracy of the journal classification systems of Web of Science and Scopus. Journal of Informetrics, 10(2), 347-364. https://doi.org/10.1016/j.joi.2016.02.003

Wang, S., \& Noe, R. A. (2010). Knowledge sharing: A review and directions for future research. Human Resource Management Review, 20(2), 115-131. https://doi.org/10.1016/j.hrmr.2009.10.001

Wasko, M. M., \& Faraj, S. (2000). It is what one does: Why people participate and help others in electronic communities of practice. The Journal of Strategic Information Systems, 9(2-3), 155-173. https://doi.org/10.1016/S0963-8687(00)00045-7

Wasko, M. M., \& Faraj, S. (2005). Why should I share? Examining social capital and knowledge contribution in electronic networks of practice. MIS Quarterly, 29(1), 35-57. https://doi.org/10.2307/25148667

Wenger, E. (1998). Communities of practice: Learning, meaning and identity. Cambridge University Press. https://doi.org/10.1017/CBO9780511803932

Wernerfelt, B. (1984). A resource-based view of the firm. Strategic Management Journal, 5(2), 171-180. https://doi.org/10.1002/smj.4250050207

Yli-Renko, H., Autio, E., \& Sapienza, H. J. (2001). Social capital, knowledge acquisition, and knowledge exploitation in young technology-based firms. Strategic Management Journal, 22(6-7), 587-613. https://doi.org/10.1002/smj.183

Zack, M. H. (1999). Developing a knowledge strategy. California Management Review, 41(3), 125-145. https://doi.org/10.2307/41166000

Zahra, S. A., \& George, G. (2002). Absorptive capacity: A review, reconceptualization, and extension. Academy of Management Review, 27(2), 185-203. https://doi.org/10.5465/amr.2002.6587995

Zander, U., \& Kogut, B. (1995). Knowledge and the speed of the transfer and imitation of organizational capabilities: An empirical test. Organization Science, 6(1), 76-92.

Zhang, J., Wu, W. P., \& Chen, R. (2018). Leveraging channel management capability for knowledge transfer in international joint ventures in an emerging market: A moderated mediation model. Industrial Marketing Management, 75, 173-183. https://doi.org/10.1016/j.indmarman.2018.05.004 